\title{
Development and Identification of Transgenic Rice Lines with Abiotic Stress Tolerance by using a Full-length Overexpressor Gene Hunting System
}

\author{
Sailila E. Abdula ${ }^{1 \S}$, Hye Jung Lee ${ }^{1 \S}$, Moo Geun Jee', Yu Jin Jung ${ }^{2}$, Kwon Kyoo Kang ${ }^{2}$, Ill Sup Nou ${ }^{3}$, Sang-Bok Lee ${ }^{4}$, \\ Won-Ha Yang ${ }^{4}$, and Yong-Gu Cho ${ }^{1 *}$ \\ ${ }^{1}$ Department of Crop Science, Chungbuk National University, Cheongju 361-763, Republic of Korea \\ ${ }^{2}$ Department of Horticulture, Hankyong National University, Ansung 456-749, Republic of Korea \\ ${ }^{3}$ Department of Horticulture, Sunchon National University, Sunchon 540-742, Republic of Korea \\ ${ }^{4}$ Chuncheon Substation, National Institute of Crop Science, Chuncheon 200-940, Republic of Korea
}

\begin{abstract}
The latest report on the draft genome of Brassica rapa sequence has been published. To elucidate the functions of these genes and to efficiently search for agriculturally useful genes, a Full-length cDNA Over-eXpressor (FOX) gene hunting system was used. The FOX library from Chinese cabbage was introduced into rice via Agrobacterium-mediated transformation. Approximately 1,150 FOX-rice lines were generated. Genomic PCR analysis indicated that the average length of FL-cDNAs introduced into individual lines was 900 1,200 bp. Basic Local Alignment System Tool (BLAST) analysis of the FL-cDNA genes revealed that 35.5\% have unknown function. Most of the randomly selected transgenic rice lines showed overexpression (92\%) of these genes relative to the wild-type Gopum. Moreover, 94\% of the 850 transgenic rice lines were moderately tolerant (slightly yellow) to cold and 9 lines were tolerant (seedlings were light green). Morphological evaluation of the transgenic rice lines showed minimal phenotypic alteration (12\%). Approximately $25.1 \%$ and $22 \%$ of the plants were significantly ahead in the days to heading and had elevated chlorophyll content, respectively. Other agronomic traits such as filled grains, number of tiller, panicle length, and culm and plant height were relatively less variable among the transgenic lines. These results provide a resource for defining genes that are associated with tolerance in transgenic rice lines.
\end{abstract}

Keywords FOX-hunting system, Full-length cDNA, Abiotic stress, Transgenic plant, Rice

\section{INTRODUCTION}

Chinese cabbage (Brassica rapa subsp. pekinensis) is one of the most important Brassica species vegetables found in Asian countries. The draft genome sequence of $B$. rapa has been recently published (The Brassica rapa Genome Sequencing Project Consortium 2011). The Chinese cabbage genome contains 41,174 protein-coding regions, whereas 27,379 genes are currently believed to exist in the Arabidopsis genome (TAIR9 information: http:// www.arabidopsis.org/). Appropriate biological experiments are needed to uncover the functions of these genes.

To accelerate the identification and characterization of gene function, various resources, including Arabidopsis and rice information, are publicly available (Nakamura et al. 2007). The Arabidopsis Information Resource (TAIR) maintains a database of genetic and molecular biology data for the model higher plant Arabidopsis thaliana (www. arabidopsis.org). Data available from TAIR includes the complete genome sequence along with gene structure, gene product information, metabolism, gene expression, DNA and seed stocks, genome maps, genetic and physical markers, publications, and information about the Arabidopsis research community. Along with this, infrastructure for rice bioinformatics (reviewed in Sasaki et al. 2005), including integrated databases such as RAP-DB (Ohyanagi et al.

Received Mar 6, 2013; Revised Mar 21, 2013; Accepted Mar 21, 2013; Published March 31, 2013

${ }^{\S}$ These authors equally contributed to this work

*Corresponding author Yong Gu Cho, ygcho@cbnu.ac.kr, Tel: +82-43-261-2514, Fax: +82-43-273-2242 
2006; Rice Annotation Project 2007) and the TIGR Rice Genome Annotation Database (Ouyang et al. 2007), BGIRIS (Zhao et al. 2004), and MOsDB (Karlowski et al. 2003), is also publicly available. The available information provides an important resource for the analysis of Brassica rapa genes.

For large-scale identification of gene function, several systems and tools have been developed to generate lossof-function mutants (Hirochika et al. 2004; An et al. 2005). These loss-of-function resources and databases are very important for tagging and hunting non-redundant genes in the rice genome. However, $29 \%$ of rice genes are estimated to exist within clustered and redundant gene families (IRGSP 2005). Therefore, it is difficult to find loss-offunction phenotypes for these duplicated genes. Moreover, when knockouts of genes confer embryonic lethality or severe developmental defects upon plants, it is impossible to the phenotypes associated with mutation or deletion of these genes (Nakamura et al. 2007). To solve this problem, FL-cDNA clones (Seki et al. 2002; Ichikawa et al. 2006) were recently developed as an alternative gain-of-function approach for the systematic elucidation of gene functions in Arabidopsis; the system is the so-called Full-length cDNA Over-eXpressor gene hunting system (FOX hunting system). FOX uses ectopic overexpression of a single or limited numbers of FL-cDNA(s) in individual transgenic plants. It generates large numbers of dominant mutations, enabling comprehensive characterization of novel and important traits and identification of the causal genes.

Studies on genetic transformation of plants have revealed an unexpected finding; the loss of mRNA encoded by either the introduced transgene or the transgene and endogenous homologous gene(s) (Vaucheret and Fagard 2001). These gene-silencing phenomena are believed to be due to methylation induced premeiotically (MIP), repeat- induced point mutation (RIP), RNA interference (RNAi), and repeat-induced gene silencing (RIGS) (Fagard and Vaucheret 2000; Marathe et al. 2000). In order to avoid this problem during our study of gene function, FL-cDNAs genes from Chinese cabbage were transformed into the rice cultivar Gopum.

In this study, clones with full-length cDNA from Chinese cabbage were sequenced, and transgenic rice plants were subsequently generated via Agrobacteriummediated transformation. The function of each clone was classified according to the annotation function based on BLAST analysis (National Center for Biotechnology Information; www.ncbi.nlm.gov). Moreover, the FOX rice lines generated were evaluated in the fields to determine their morpho-agronomic characteristics and phenotypic traits, as well as their responses to cold and salinity.

\section{MATERIALS AND METHODS}

\section{Plant materials and field trials}

The rice variety Gopum was used as the wild-type strain in the generation of transgenic rice. Regenerated plants were transplanted in soil consisting of 50\% compost and $50 \%$ earth soil and acclimatized for 2 weeks in a greenhouse. Young leaves were collected for genomic DNA analysis using pBigs_sfll and hpt primers (GenBank Accession No. AF234296). Subsequently, plants that were confirmed to carry the gene insert were harvested, and the $T_{1}$ seeds were used in the succeeding generation in the field following the protocol of Sun et al. (2011). The varieties were sown in a seedling-growing tray and placed in the greenhouse for 3 weeks in May, 2011. Grown seedlings were transplanted in the experimental farm spaced at $30 \times 15 \mathrm{~cm}$ with one seedling per hill and arranged in randomized complete block design replicated three times. The cultivation and management were performed according to the standards of the experimental farm in Chungbuk National University.

\section{Vector construction with full-length cDNAs}

Brassica rapa clones with full-length cDNA were ligated into the pBigs_sfiI vector. The recombinant vector carrying these clones was constructed under the control of the $p U B I-1$ promoter and NOS terminator, as shown in Fig. 1. Each clone was grown in Luria-Bertani medium containing $50 \mathrm{mg} / \mathrm{L}$ kanamycin sulfate and incubated at $28^{\circ} \mathrm{C}$ on a shaker for $24 \sim 36 \mathrm{~h}$. Plasmid DNA, extracted according to the Qiagen plasmid kit (Cat. No. 12125) protocol, was used in the sequence analysis. 


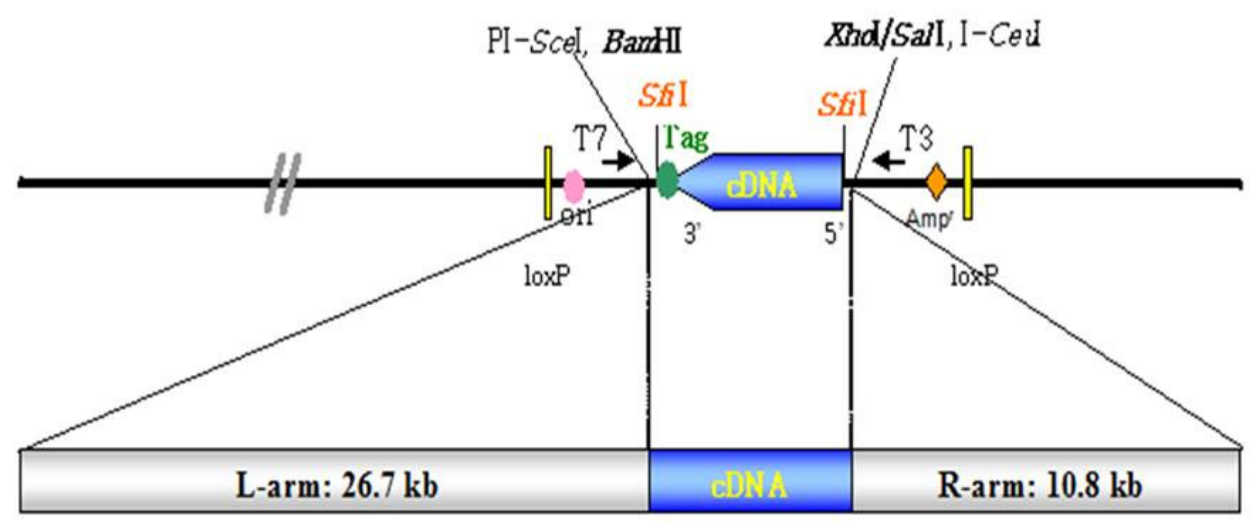

Fig. 1. Schematic diagram of the binary Ti plasmid pFLCIII containing the full length cDNA from Chinese cabbage. pBigs vector was consisted of two different SfiI sites [SfiI(A) and SfiI(B)].

\section{Generation of transgenic rice}

Transgenic rice was generated following the protocol of Toki et al. (2006), with some modifications (Lee et al. 2011). Briefly, dehulled mature seeds of the japonica rice cultivar Gopum were sterilized with $70 \%$ ethanol for $5 \mathrm{~min}$. These seeds were further sterilized by strong shaking in $30-35 \mathrm{~mL}$ of $2.5 \%$ sodium hypochlorite containing one drop of Tween 20 for $15 \mathrm{~min}$. The sterilized seeds were washed 20 times in distilled water, dried in the clean bench for $30 \mathrm{~min}$, and then inoculated on embryogenic callus induction (2N6) medium (Table 1). This set up was incubated in the dark at $32^{\circ} \mathrm{C}$ for 7-10 days.

Agrobacterium strain EHA105 harboring binary $\mathrm{Ti}$ plasmid $p F L C I I I$ (Fig. 1) containing the full- length cDNA gene was cultured on $\mathrm{AB}$ medium containing $50 \mathrm{mg} / \mathrm{L}$ kanamycin sulfate solidified with $1.5 \%$ agar incubated for

Table 1. Identified transgenic rice with cold, salinity and drought tolerance.

\begin{tabular}{|c|c|c|c|c|}
\hline Clone & $\begin{array}{l}\text { Tolerance to } \\
\mathrm{NaCl} \text { stresses } \\
(130 \mathrm{mM})\end{array}$ & $\begin{array}{c}\text { Tolerance to } \\
\text { Cold }\end{array}$ & $\begin{array}{c}\text { Drought } \\
(20 \% \text { PEG })\end{array}$ & Gene function (based on BLAST) \\
\hline BR5 & - & ++ & - & Unknown function \\
\hline BR7 & + & ++ & + & DEAD BOX RNA helicase RH15 \\
\hline BR15 & - & + & + & UDP-glucose 4-epimerase \\
\hline BR37 & + & ++ & + & CBL-interacting protein kinase 1 \\
\hline BR39 & - & ++ & - & Carbon-monoxide oxygenase (ACYB-1) \\
\hline BR40 & + & + & - & Phosphatase 2C, putative / PP2C \\
\hline BR74 & + & + & - & Haloacid dehydrogenase-like hydrolase \\
\hline BR91 & + & + & - & Unknown protein (AT3G12210) \\
\hline BR115 & + & ++ & + & At5g25810 mRNA \\
\hline BR119 & + & ++ & + & Unknown function \\
\hline BR503 & - & ++ & - & Unknown function \\
\hline BR522 & - & ++ & - & Hypothetical protein \\
\hline BR541 & - & ++ & - & Light harvesting complex PSII \\
\hline BR547 & - & ++ & - & UDP galactose transporter 3 \\
\hline
\end{tabular}

+ , tolerant; ++ , highly tolerant; -, susceptible. Wild type, Gopum is moderately tolerant to cold but susceptible to either salinity and drought. Evaluation was based on SES for Rice (IRRI-SES, 2002) 
Plant Breed. Biotech. 2013 (March) 1(1):33 48

3 days at $28^{\circ} \mathrm{C}$ in the dark. Agrobacterium culture was scraped from the plates and suspended in AAM medium to yield an $\mathrm{OD}_{600}$ of approximately 0.3. Pre-cultured seeds were immersed in the Agrobacterium suspension by gently inverting the tube for $15 \mathrm{~min}$, blotted dry with a sterilized filter paper to remove excess bacteria. The seeds were transferred onto a sterilized filter paper that had been moistened with $0.5 \mathrm{~mL}$ of AAM medium placed on 2N6-AS medium solidified with $0.4 \%$ Gelrite. After 3 days of co-cultivation at $25^{\circ} \mathrm{C}$ in the dark, seeds were washed 5 times in sterilized water, and then washed once in sterilized water containing $500 \mathrm{mg} / \mathrm{L}$ carbenicillin to remove Agrobacterium cells. The seeds were rapidly blotted dry on a sterilized filter paper and cultured on N6D (Table 2) medium containing $50 \mathrm{mg} / \mathrm{L}$ hygromycin and $400 \mathrm{mg} / \mathrm{L}$ carbenicillin under continuous light at $32^{\circ} \mathrm{C}$ for 2 weeks. Proliferating calli arising from the scutellum were transferred to REIII (Table 2) medium. Plantlets arising from the calli were transferred to HF medium to induce root formation.

\section{DNA extraction and PCR analysis}

Genomic DNA was extracted as described by Cho et al. (2007) with some modifications. The relative purity and concentration of extracted DNA was estimated using NanoDrop-1000 (NanoDrop Technologies, Inc. USA). PCR analyses were performed using HPT-Fw (5'-GGATTTCGGCTCCAATGTCCTGACGGA-3') and HPT-Rv (5'-CTTCTACACAGCCATCGGTCCAGA-3') primers to check the introgression of hygromycin phosphotransferase gene ( $h p t)$ and $p B i g s \_S f i I$-Fw (5'-TATTCGGAGAGGGTACGTATTTTTAC-3') and pBigs_sfil-Rv (5'-GCAACAGGATTCAATCTTAAGAAACT-3') to check the introduction of the full-length cDNA gene.

\section{Southem blot analysis}

For DNA blot analysis, $10 \mu \mathrm{g}$ of genomic DNA was extracted as mentioned above. A digoxigenin (DIG) probe was synthesized according to the manufacturer's instructions (PCR DIG Probe Synthesis Kit; Roche Molecular Biochemicals, USA). The template for the probe synthesis was

Table 2. Composition of media used for tissue culture and transformation of rice.

\begin{tabular}{|c|c|}
\hline Medium & Composition \\
\hline $\begin{array}{l}\text { 2N6 (Embryogenic callus } \\
\text { induction) }\end{array}$ & $\begin{array}{l}4 \mathrm{~g} / \mathrm{L} \text { Chu }\left(\mathrm{N}_{6}\right) \text { medium (Micro and macro elements including vitamins) (Cat. No. C0204, Duchefa } \\
\text { Biochemie B.V.), } 0.3 \mathrm{~g} / \mathrm{L} \text { Casein hydrolysate, } 0.5 \mathrm{~g} / \mathrm{L} \text { Glutamine, } 0.5 \mathrm{~g} / \mathrm{L} \text { Proline, } 30 \mathrm{~g} / \mathrm{L} \text { Sucrose, } 2 \\
\mathrm{mg} / \mathrm{L} \text { 2.4-D, } 2.5 \mathrm{~g} / \mathrm{L} \text { Gelrite (pH 5.8) }\end{array}$ \\
\hline $\begin{array}{l}\text { AB } \\
\text { (Agrobacterium culture) }\end{array}$ & $\begin{array}{l}5 \mathrm{~g} / \mathrm{L} \text { Glucose, } 15 \mathrm{~g} / \mathrm{L} \text { Bacto agar, } 3 \mathrm{~g} / \mathrm{L} \mathrm{K} \mathrm{K}_{2} \mathrm{HPO}_{4}, 1 \mathrm{~g} / \mathrm{L} \mathrm{NaH}_{2} \mathrm{PO}_{4}, 1 \mathrm{~g} / \mathrm{L} \mathrm{NH}_{4} \mathrm{Cl}, 0.3 \mathrm{~g} / \mathrm{L} \mathrm{MgSO}_{4} \cdot \\
7 \mathrm{H}_{2} \mathrm{O}, 0.15 \mathrm{~g} / \mathrm{L} \mathrm{KCl}, 13.25 \mathrm{mg} / \mathrm{L} \mathrm{CaCl}_{2} \cdot 2 \mathrm{H}_{2} \mathrm{O}, 2.5 \mathrm{mg} / \mathrm{L} \mathrm{FeSO}_{4} \cdot 7 \mathrm{H}_{2} \mathrm{O}\left(\mathrm{pH}_{7} 7.2\right)\end{array}$ \\
\hline $\begin{array}{l}\text { AAM-AS (Agrobacterium } \\
\text { suspension and infection) }\end{array}$ & $\begin{array}{l}0.12 \mathrm{~g} / \mathrm{L} \mathrm{MgSO} \\
4\end{array}$ \\
\hline 2N6-AS (Co-culture) & $\begin{array}{l}4 \mathrm{~g} / \mathrm{L} \mathrm{Chu}\left(\mathrm{N}_{6}\right) \text { medium (Micro and macro elements including vitamins) (Cat. No. C0204, Duchefa } \\
\text { Biochemie B.V.), } 0.3 \mathrm{~g} / \mathrm{L} \text { Casein hydrolysate, } 0.5 \mathrm{~g} / \mathrm{L} \text { Glutamine, } 0.5 \mathrm{~g} / \mathrm{L} \text { Proline, } 30 \mathrm{~g} / \mathrm{L} \text { Sucrose, } 10 \\
\mathrm{~g} / \mathrm{L} \text { Glucose, } 2 \mathrm{mg} / \mathrm{L} 2.4-\mathrm{D}, 20 \mathrm{mg} / \mathrm{L} \text { Acetosyringone, } 0.15 \mathrm{~g} / \mathrm{L} \text { Dithiothreitol, } 0.25 \mathrm{~g} / \mathrm{L} \text { Sodium } \\
\text { thiosulfate, } 5 \mathrm{mg} / \mathrm{L} \text { Silver nitrate }(\mathrm{pH} 5.2)\end{array}$ \\
\hline $\begin{array}{l}\text { N6D (Transgenic callus } \\
\text { selection) }\end{array}$ & $\begin{array}{l}4 \mathrm{~g} / \mathrm{L} \text { Chu (N6) medium (Micro and macro elements including vitamins) (Cat. No. C0204, Duchefa } \\
\text { Biochemie B.V.), } 0.3 \mathrm{~g} / \mathrm{L} \text { Casein hydrolysate, } 0.5 \mathrm{~g} / \mathrm{L} \text { Glutamine, } 0.5 \mathrm{~g} / \mathrm{L} \text { Proline, } 30 \mathrm{~g} / \mathrm{L} \text { Sucrose, } 2 \\
\mathrm{mg} / \mathrm{L} \text { 2.4-D, } 2.5 \mathrm{~g} / \mathrm{L} \text { Gelrite, } 250 \mathrm{mg} / \mathrm{L} \text { Cefotaxime, } 50 \mathrm{mg} / \mathrm{L} \text { Hygromycin (pH 5.8) }\end{array}$ \\
\hline REIII (Shoot formation) & $\begin{array}{l}4.4 \mathrm{~g} / \mathrm{L} \text { MS medium including vitamins (Cat. No. M0222, Duchefa Biochemie B.V.), } 0.5 \mathrm{mg} / \mathrm{L} \mathrm{NAA} \text {, } \\
2 \mathrm{mg} / \mathrm{L} \text { 6-BA, } 20 \mathrm{~g} / \mathrm{L} \text { Sucrose, } 30 \mathrm{~g} / \mathrm{L} \text { Sorbitol, } 2 \mathrm{~g} / \mathrm{L} \text { Casamino acid, } 250 \mathrm{mg} / \mathrm{L} \text { Cefotaxime, } 80 \mathrm{mg} / \mathrm{L} \\
\text { Hygromycin, } 4 \mathrm{~g} / \mathrm{L} \text { Gelrite (pH 5.8) }\end{array}$ \\
\hline HF (Root formation) & $\begin{array}{l}4.4 \mathrm{~g} / \mathrm{L} \text { MS medium including vitamins (Cat. No. M0222, Duchefa Biochemie B.V.), } 30 \mathrm{~g} / \mathrm{L} \text { Sucrose, } \\
\text { 7.5 g/L Plant agar, } 250 \mathrm{mg} / \mathrm{L} \text { Cefotaxime, } 80 \mathrm{mg} / \mathrm{L} \text { Hygromycin (pH 5.8) }\end{array}$ \\
\hline
\end{tabular}


from the vector containing the full-length cDNA clone. The forward/ reverse primers used for the synthesis of the probe were 5'-GATTAAGCATCCAAATGTTGTTCA-3' and 5'-CCTACGAGCCTCATCTTCT-3'. The PCR amplification was initiated with a denaturation at $95^{\circ} \mathrm{C}$ for $2 \mathrm{~min}$, followed by 30 cycles of $95^{\circ} \mathrm{C}$ for $30 \mathrm{~s}, 56^{\circ} \mathrm{C}$ for $30 \mathrm{~s}$, and $72^{\circ} \mathrm{C}$ for $60 \mathrm{~s}$, and the final elongation step at $72^{\circ} \mathrm{C}$ for 7 min. Ten micrograms of genomic DNA was digested overnight at $37^{\circ} \mathrm{C}$ with the restriction enzymes $\mathrm{BamHI}$ and EcoRI. The digested DNA was subjected to electrophoresis in a $0.8 \%$ agarose gel and transferred to a Hybond- $\mathrm{N}^{+}$ membrane (Amersham Biosciences, USA), according to the manufacturer's instructions. The membrane was prehybridized at $42^{\circ} \mathrm{C}$ in a DIG East Hyb buffer for $1 \mathrm{~h}$. A DIG-labeled probe was then added $(2 \mu \mathrm{L}$ of probe $/ \mathrm{mL}$ of buffer) and hybridization was carried out overnight at $42^{\circ} \mathrm{C}$. The membrane was washed twice with a lowstringency washing solution $(2 \times \mathrm{SSC}, 0.1 \% \mathrm{SDS})$ at $25^{\circ} \mathrm{C}$ for $5 \mathrm{~min}$, and then washed twice with a high-stringency solution $(0.1 \times \mathrm{SSC}, 0.5 \% \mathrm{SDS})$ at $68^{\circ} \mathrm{C}$ for $15 \mathrm{~min}$. The DIG-labeled DNA was detected according to the manufacturer's instructions (DIG Nucleic Acid Detection Kit; Roche Molecular Biochemicals, USA).

\section{Cold, salinity, and drought tolerance screen}

Cold evaluation was conducted at the Chuncheon Experimental Station of the Rural Development Administration, Korea. About 50 seeds were directly seeded into germination trays $(60 \times 30 \times 3.5 \mathrm{~cm})$ with a soil-free medium of steam-sterilized sand with peat compost and vermiculite and allowed to grow for 7 weeks before cold treatment at a water temperature of approximately $13^{\circ} \mathrm{C}$, and an air temperature of $30-35^{\circ} \mathrm{C}$.

For the salinity and drought tolerance test, styrofoam seedling floats were fabricated as described by Manigbas et al. (2011). Holes were drilled at the surface of the styrofoam with a nylon net supporting the bottom. Two pre-germinated seeds were placed on each hole. Seedling floats were placed on each tray comprising a replication of two, with 20 seedlings per entry. The growing plants were supplied with Murashige and Skoog (MS) solution at 4.4 gram per liter to maintain good growth and healthy seedlings throughout the experiment. After 2 weeks, solutions of $130 \mathrm{mM} \mathrm{NaCl}$ and $20 \%$ PEG were used to induce salinity and drought, respectively on rice seedlings; this solution was changed after 8 days. The lines were scored after 2 weeks, or when the susceptible check showed high susceptibility by using the standard evaluation system for rice (IRRI-SES 2007).

\section{RT-PCR analysis}

Total RNA was extracted from the transgenic lines and wild-type Gopum plant by using the RNeasy Plant Mini Kit (QIAGEN, Maryland, USA), according to the manufacturer's instructions. This process was repeated in all experiments requiring RNA extraction. The relative purity and concentration of extracted RNA was estimated using NanoDrop-1000 spectrophotometer (NanoDrop Technologies, Inc. USA), and stored in a $-80^{\circ} \mathrm{C}$ freezer. Total RNAs were cleaned using DNaseI, and first-strand cDNA synthesis was performed by reverse transcription of mRNA using Oligo $(\mathrm{dT})_{20}$ primer and SuperScript ${ }^{\mathrm{TM}}$ III Reverse Transcriptase.

The nucleotide sequence of each of the randomly selected clones was used to design primer pairs (Table 3).The specific sequences of the primer pairs were used in a semi-quantitative reverse transcription PCR (RT-PCR). Actin primers were used as loading controls and used as internal controls for normalization of the quantitative RT-PCR reaction.

\section{Statistical analysis}

Data requiring statistical analysis were computed using the Statistix version 8 (www.statistix.com). Significant P values were analyzed by using the two-sided Dunnett's multiple comparison, with the wild-type Gopum as control by using the same software. The frequency distribution of various agronomic traits and sequences was determined using Microsoft Excel 2007.

\section{Nucleotide sequence analysis}

All the inserted sequences were checked using the BLAST program in NCBI sequence database and another program in the GenBank/EMBL/DDBJ sequence database. The open reading frame (ORF) and conserved domain were 
- Plant Breed. Biotech. 2013 (March) 1(1):33 48

Table 3. Primers sequences used in the RT-PCR analysis and annotation of gene function by the NCBI database.

\begin{tabular}{|c|c|c|c|}
\hline Gene & Forward Primer & Reverse Primer & Gene Function \\
\hline BR 2 & 5'-GTGTTGACGGACGTTGTGAC-3' & 5'-CCGGGTCTAGATCTGTTCCA-3' & Cysteine protease 1 \\
\hline BR 4 & 5'-TGCCGTTATGCCATTTATGA-3' & 5'-ATCAAGACCCATCTCGGTTG-3' & Actin binding/depolymerizing factor 2 \\
\hline BR 7 & 5'-GCATTTCCTAAAGCCACCAA-3' & 5'-CCAGGAGTAGGCTCGATCTG-3' & $\begin{array}{l}\text { DEAD BOX RNA helicase RH15 - like } \\
\text { protein }\end{array}$ \\
\hline BR 11 & 5'-AACGAGAGAGGAGGGATGAT-3' & 5'-CCAGAGGAGCTTCAGGGTTG-3' & Alcohol dehydrogenase 1 \\
\hline BR 15 & 5'-GCTTTGCGTGCCTTCTTATC-3' & 5'-GAAGAACCCACTTGGCAAAA-3' & UDP-glucose 4 -epimerase 1 \\
\hline BR 22 & 5'-ACTTGGCGAGCTTGACTCAT-3' & 5'-GAGCATTTCTCCTGCGTTTC-3' & Hydrogen transporting ATPase \\
\hline BR 23 & 5'-AATGCACGGAATAGAGG-3' & 5'-CAGGTCCTCATTACCGGTGT-3' & $\begin{array}{l}\text { Endoplasmic reticulum auxin-binding } \\
\text { protein } 2 \mathrm{mRNA}\end{array}$ \\
\hline BR 37 & 5'-ATCGGAGGCAGCAAGTCAAGCG-3' & 5'-CTCCATCGTAGCCTCCGTCAT-3' & CBL-interacting protein kinase 1 \\
\hline BR 39 & 5'-CAGGAAAAGAAGCGGATGAG-3' & 5'-AGTGTGCCTGTCATCGTGAG-3' & Carbon-monoxide oxygenase (ACYB-1) \\
\hline BR 43 & 5'-AACTCCAAGCGTTGGATATG-3' & 5'-TCTCCAGGTTCGTTTGCTCT-3' & Hypothetical protein \\
\hline BR 47 & 5'-CTAATGCTGACGGTGGGTTT-3' & 5'-ACGAAAAGGTCGAAAGCTGA-3' & Unknown gene function \\
\hline BR 61 & 5'-CCTCTGATCCCACCACACTT-3' & 5'-TTAGGAGCAGCACACACTGG-3' & Rubredoxin family protein \\
\hline BR 64 & 5'-AGAAGCTGATGGCTCGGTTA-3' & 5'-СCTCTTCTCGGCTGAACAAC-3' & $\begin{array}{l}\text { Beta-lg-H3 domain-containing protein } \\
\text { (FLA18) }\end{array}$ \\
\hline BR 68 & 5'-CCTTACCGCCGCCACCATGTTT-3' & 5'-AGGTGTCAAAAGTCGGGTTG-3' & Unknown gene function \\
\hline BR 72 & 5'-ACCAAACACTCACCGGAGTC-3' & 5'-ATCACCACCCGCAAGTAAAG-3' & Unknown protein function \\
\hline BR 74 & 5'-CGATGTTCGATGTCCTCCTT-3' & 5'-GGCTCGATCATCGTCATTCT-3' & $\begin{array}{l}\text { Haloacid dehalogenase-like } \\
\text { family protein }\end{array}$ \\
\hline BR 77 & 5'-CATCTACCGAGCAACAGCAA-3' & 5'-AATGCCCAATCCATACCAAA-3' & $\begin{array}{l}\text { Unknown } \\
\text { (Zeamays clone 92871) }\end{array}$ \\
\hline BR 91 & 5'-TGGAAGCTCTCTCGTGGAA-3' & 5'-CTCGTCGGACATAAATGGT-3' & Unknown protein \\
\hline BR 119 & 5'-GTATCACTCTCGGGGTTCCA-3' & 5'-CCAAACAAATGGGACAATCC-3' & Unknown gene function \\
\hline BR 129 & 5'-GTGGAGGGAGTCAACGATGT-3' & 5'-CCGAGTCCCTGCGATATTTA-3' & $\begin{array}{l}\text { Dimethylmenaquinone methyltransferase } \\
\text { family protein }\end{array}$ \\
\hline BR 192 & 5'-CATAAGGTACGCGACGGTTT-3' & 5'-ACTAAAGCAGCTTCGGTCCA-3' & Glycosyltransferase family protein \\
\hline BR 195 & 5'-CACTGGAGTTGACCCAAC-3' & 5'-AATGCTAAGGGCACCAACAC-3' & Aspartate aminotransferase 2 \\
\hline BR 289 & 5'-TGATCAGATGGAGTGGTGGA-3' & 5'-CTCCTCGCTTGTTGGAAGAC-3' & $\begin{array}{l}\text { Plastid-lipid associated protein PAP / } \\
\text { fibrillin family protein }\end{array}$ \\
\hline
\end{tabular}

generated using the BLASTN program (http://www.ncbi. nlm.nih.gov/). Sequence alignment, ORF translation, molecular weight calculation of the predicted proteins, and structural analysis of the deduced proteins were carried out by DNAStar's Lasergene sequence analysis software (www.dnastar.com).

\section{RESULTS}

\section{Characterization of selected clones from FOX hunting system}

Agrobacterium clones containing FL-cDNAs genes from Brassica rapa were subjected to genomic PCR using forward and reverse primers (pBigs_SfiI-Fw and pBigs_ sfil-Rv) derived from the flanking sequences. Of the 933 clones analyzed, $80 \%$ showed single bands, while $4 \%$ showed multiple fragments (Fig. 2A). The remaining clones $(16 \%)$ did not undergo fragment amplification. All the amplified single PCR fragments bearing the integrated FL-cDNA(s) from B. rapa clones were used to generate their respective sequences. The sizes of the introduced FL-cDNAs were variable, ranging from 100 to $2,400 \mathrm{bp}$ (Fig. 2B). About $5 \%$ of the clones were smaller than 500 bp, whereas $95 \%$ ranged from 600 to 2,400 bp.

The Basic Alignment System Tool (BLAST) provided by the National Center for Biotechnology Information (www.ncbi.nlm.nih.gov) was used to determine the functional 
annotation of each clone. The frequency distribution based on function is presented in Fig. 2C. Variable gene function was observed from the viewpoint of molecular as well as biological importance. Most clones (32.15\%) were characterized as having an unknown biological/molecular gene function. About $0.64 \%$ of clones appeared to possess functions related to catalytic activity, and $5.04 \%$ appeared to exhibit some binding activity. Transcription- and translation-related functions accounted for $2.36 \%$ of the clones. Moreover, $1.39 \%$ of the clones had homology with zinc finger-related proteins. A large number of other functions, each with a lower frequency than those reported above, collectively accounted for another $35.16 \%$ of the clones (Fig. 2C). These genes provide important resources for studying their function in plants.

\section{Generation of transgenic rice lines}

Using the protocol described by Lee et al. (2011) and modified on the basis of that described by Toki et al. (2006), transgenic rice plantlets were regenerated within a month starting from the aseptic culture of the mature seeds (Fig. 3A). The plantlets were subjected to PCR analysis to verify the integration of FL-cDNAs. The genomic DNA PCR analysis is represented in Fig. 3B. Most of the regenerated plants $\left(\mathrm{T}_{0}\right)(73 \%)$ contained the expected band sizes (Fig. 3C), indicating the high efficiency of the transformation method. About $20 \%$ of the transgenic plants had hpt gene, whereas $2 \%$ had only FL-cDNAs gene.

The confirmed FOX rice lines were advanced in the succeeding planting season from 2009 to 2011. So far, we have propagated transgenic rice up to the fourth generation (T4) (Table 4). Most of the transgenic rice lines were in the $\mathrm{T}_{1}$ generation that constituted 470 independent rice lines in 137 independent clones. In the $T_{2}$ generation, 408 lines with 88 gene inserts were produced. In the $\mathrm{T}_{3}$ generation, 46 lines were generated. In summary, a total of 250
A

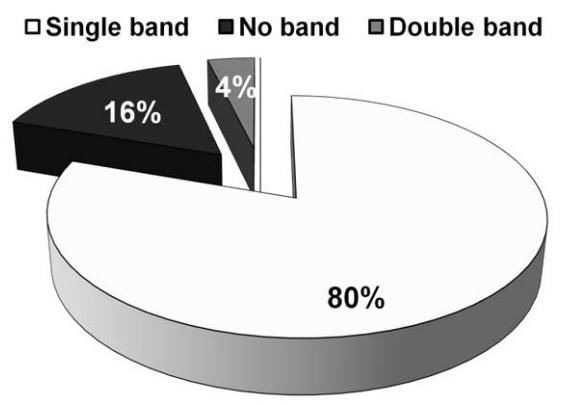

C

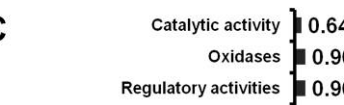

Zinc Finger protein related activities 1.39 Reductases 1.71

RNA/DNA/nucleotide binding 1.82

Kinases 2.14

Precursors 2.25

Hydrolases 2.25

Transport/Transport Activity 2.36

Transcription/translation activity $\mathbf{2 . 3 6}$

Transferases 2.89

Protein binding 2.89

Ribosomal protein activities 3.00

Other binding 5.04

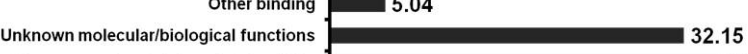

Other enzyme/protein/or related activity \begin{tabular}{lllll}
\hline & 35.16 \\
\hline
\end{tabular}
B

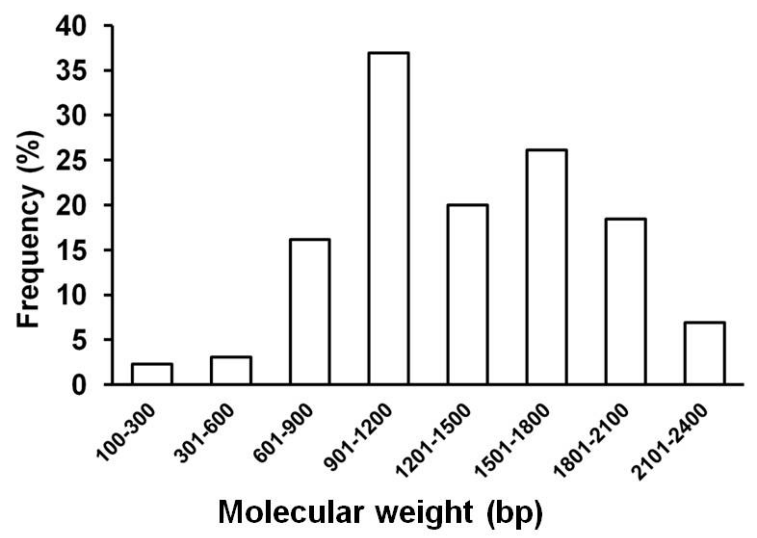

Fig. 2. PCR amplification and BLAST analyses of 933 clones. (A) Pattern and numbers of cDNA-containing fragments. (B) frequency of gene according to the length (bp) of FOX cDNA library. (C) NCBI database annotation based on gene function. 
A

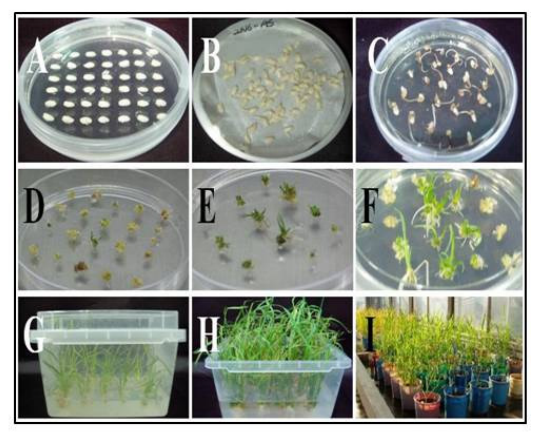

C

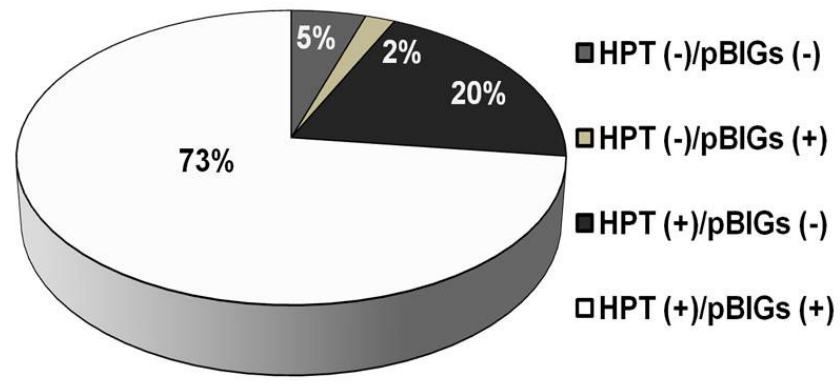

B

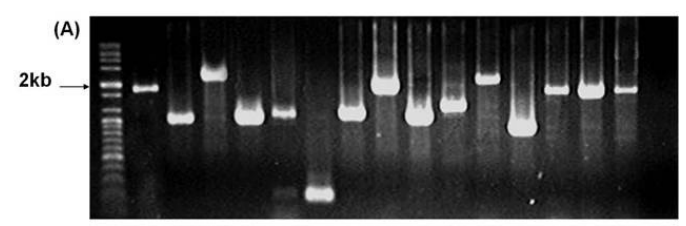

(B)

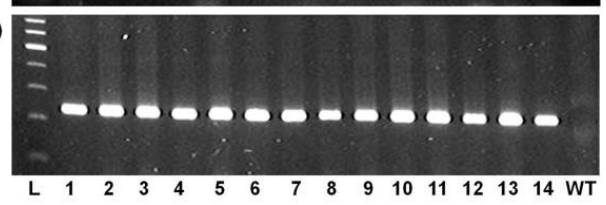

Fig. 3. Development, PCR analysis and transformation efficiency in the generation of transgenic rice. (A) Development of selected 250 clones from FL-cDNA through Agrobacterium-mediated transformation (A) callus formation; (B) inoculation; (C) callus selection using hygromycin (D), (E) and (F) shoot formation and elongation; (G) and (H) root formation and elongation; (I) acclimatization ; (B) Genomic PCR confirmation of inserted genes using T1 plants by pBigs Sfil (a) and HPT (b) primers in $1 \%$ agarose gel. $\mathrm{L}=$ Ladder, $1=\mathrm{BR} 2,2=\mathrm{BR} 4,3=\mathrm{BR} 7,4=\mathrm{BR} 23$, 5=BR47, 6=BR61, 7=BR74, 8=BR91, 9=BR129, 10=BR192, 11=BR195, 12=BR174, 13=BR15, 14=BR37, WT= wild type; (C) The efficiency of Agrobacterium-mediated transformation based on the genomic PCR analysis of 1,072 T0 generation rice lines using hpt and pBigs_SfiI primers.

Table 4. Number of transgenic rice lines produced, confirmed gene inserts and its respective generation.

\begin{tabular}{|c|c|c|}
\hline Generation* & Confirmed no. of gene inserts & No. of lines \\
\hline $\mathrm{T}_{1}$ & 137 & 470 \\
\hline $\mathrm{T}_{2}$ & 88 & 408 \\
\hline $\mathrm{T}_{3}$ & 14 & 46 \\
\hline $\mathrm{T}_{4}$ & 11 & 226 \\
\hline Total & 250 & 1,150 \\
\hline
\end{tabular}

independent clones were inserted into the rice genome, leading to the generation of 1,150 independent transgenic lines (Table 4). These transgenic rice lines are a valuable resource for future analyses designed to determine the functions of each gene.

\section{Gene copy number}

To examine the gene copy number of 31 randomly selected lines, we used the digoxigenin (DIG) system method (Roche Molecular Biochemicals, USA). Because of variability in the gene sequences, we used hpt gene as probe. Our results showed that most of the transgenic lines 
have a single copy number (Fig. 4A). However, in BR 37, which encodes CBL-interacting protein kinase 1 , two gene copies were present in each of 4 lines (numbers $3,4,6,7$ ). Similarly, in BR 15, which encodes UDP-glucose-4epimerase 1, two lines had two copies of the gene (numbers 12 and 13). Furthermore, in clone BR 4, two copies of the introduced gene (actin-depolymerizing factor 2) were observed. The rest of the lines harbored transgenes at single copy. The variability in copy number has been reported in previous studies (Schrider and Hahn 2010). This may be due to the positional effect of the gene during transformation (Gelvin 2003).

\section{Expression analysis of transgenes}

To examine whether the expression of transgenes was elevated at the molecular level, 24 transgenic lines encoding different gene inserts were randomly selected. Expression of these 24 genes was examined by semiquantitative RT-PCR analysis with individual gene-specific primers (as shown in Table 3) by using the young shoots of

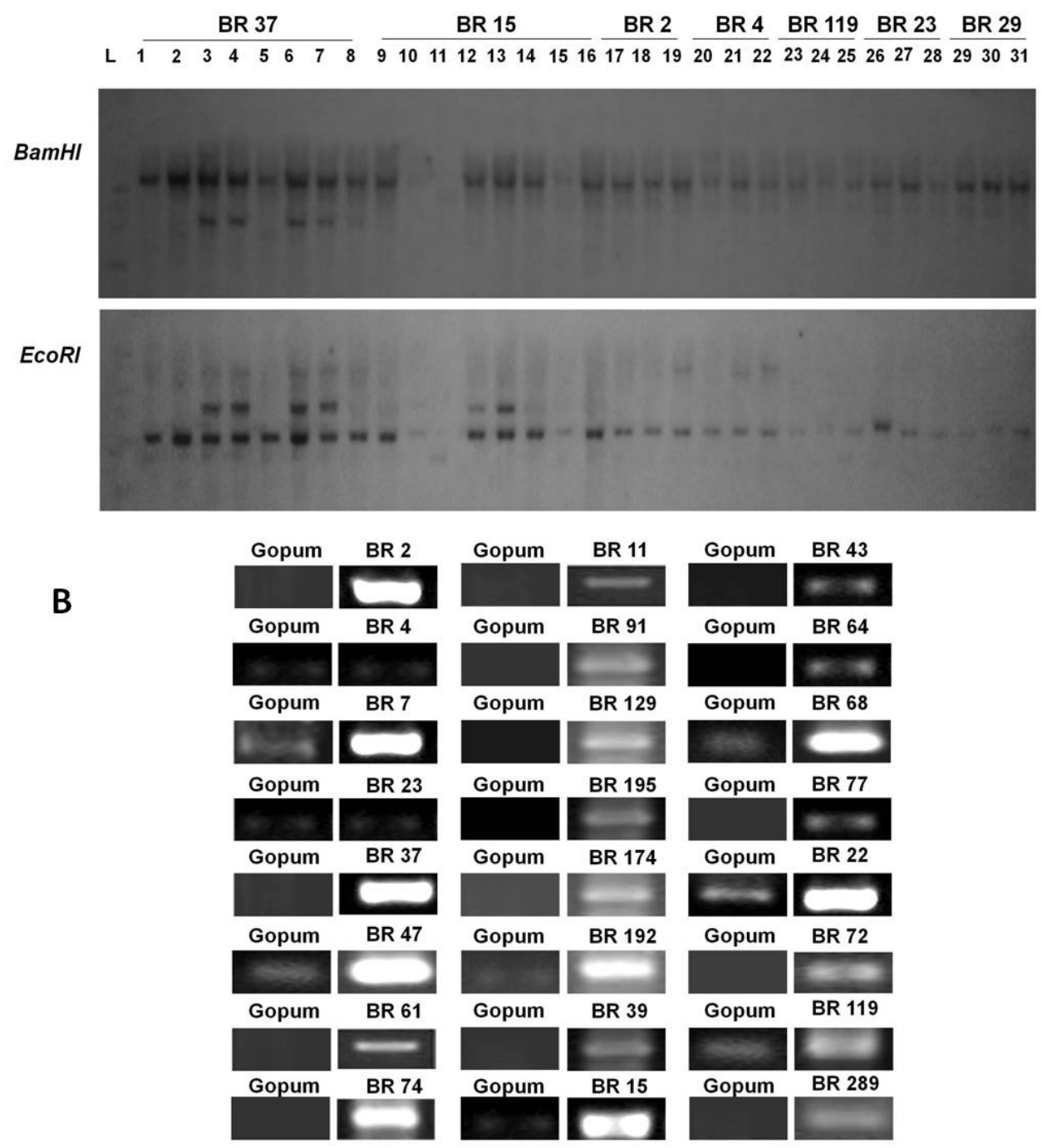

Fig. 4. Southern blot analysis and expression pattern of randomly selected FOX rice lines. (A) hpt gene was used as probe using a non-isotope method (dioxiginin). BR 37 (BrCIPK1, CBL-interacting protein kinase 1); BR15 (BrUGE1, UDP-glucose-4-epimerase 1); BR2 (BrCP1, Cysteine protease 1); BR4 (Actin depolymerizing factor 2); BR119 (Unknown function); BR23 (ER auxin-binding protein 2); BR29 (Phospholipase C). (B) RT-PCR of selected rice lines using their respective primer pairs (Supplemental Table 2. Rice actin was used as loading adjustments (data not shown). Gopum was the wild type. 
each rice seedling. mRNA expression was observed in all 24 genes with varying band intensities (Fig. 4B). Strong mRNA expression was observed in BR 2 (cysteine protease 1), BR 7 (DEAD box RNA helicase RH15), BR 37 (CBL-interacting protein kinase 1), BR 47 (unknown gene function), BR 74 (haloacid dehalogenase- like hydrolase), BR 192 (glycosyltransferase), BR 15 (UDP-glucose-4epimerase 1), BR 68 (unknown function), and BR 22 (hydrogen-transporting ATPase). Moreover, weak mRNA expression was observed in BR 4 and BR 23 lines encoding an actin-binding/depolymerizing factor 2 and endoplasmic reticulum auxin-binding protein 2 mRNA, respectively.

\section{Response of transgenic rice lines against cold and salinity}

To determine the response of transgenic rice lines to cold, 840 independent lines comprising 250 genes were evaluated at the Chuncheon Experimental Station of the
Rural Development Administration, Korea. Most of the transgenic rice lines (94\%) were moderately tolerant (seedlings were light yellow) to cold and about 5\% were moderately susceptible (seedlings were turning brown) (Fig. 5A). Interestingly, 9 (1\%) of the transgenic lines were tolerant (seedlings were light green) (Table 1). Of the 9 tolerant lines, 4 encode genes with an unknown function (BR 5, BR 119, BR 522, BR 503). Other tolerant lines encoded UDP-galactose transporter 3 (BR 457), DEAD box RNA helicase RH 15 (BR 7), Arv1-like protein (BR 115), carbon-monooxide oxygenase (ACYB-1) (BR 39) and light harvesting complex PSII (BR 541). Conversely, we found 6 transgenic lines that were susceptible to cold stress, 4 of which encode an unknown gene function. The rest of the transgenic lines responded to the cold in a manner indistinguishable from wild-type Gopum.

In the salinity test, $85 \%$ of the transgenic rice lines were found to be highly susceptible (almost all plants were dead

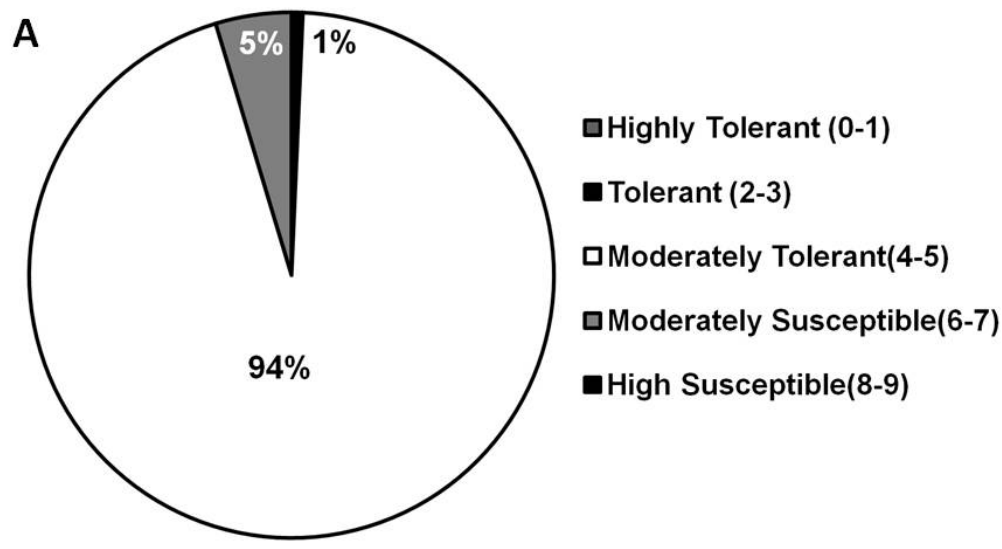

B

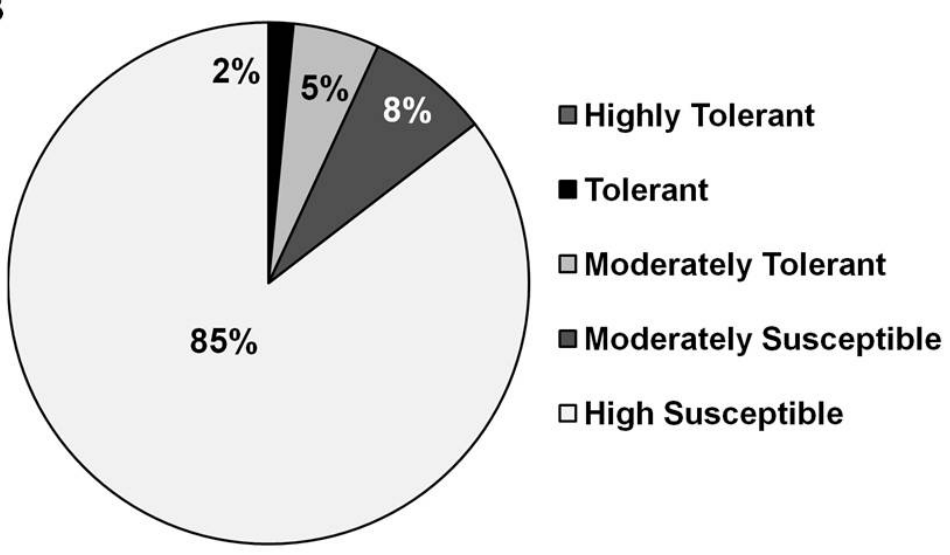

Fig. 5. Response of FOX rice lines against cold and salinity (see materials and methods for details). 
or dying) (Fig. 5B). However, we found 7 tolerant transgenic lines (nearly normal growth and tillering) (Table 1). These lines were BR 7 (unknown gene function), BR 37 (CBL-interacting protein kinase 1), BR 40 (Phosphatase 2C), BR 74 (Haloacid dehalogenase-like hydrolase), BR 91 (unknown gene function), BR 115 (BREB subfamily A-4 ERF/AP2 transcription factor), and BR 119 (unknown gene function). Moreover, 15 lines were shown to be moderately tolerant to salinity stress (their growth was nearly normal, but plants had some rolled leaves). These tolerant lines are an important resource for studying the mechanisms of resistance, and may eventually facilitate crop improvement in the future.

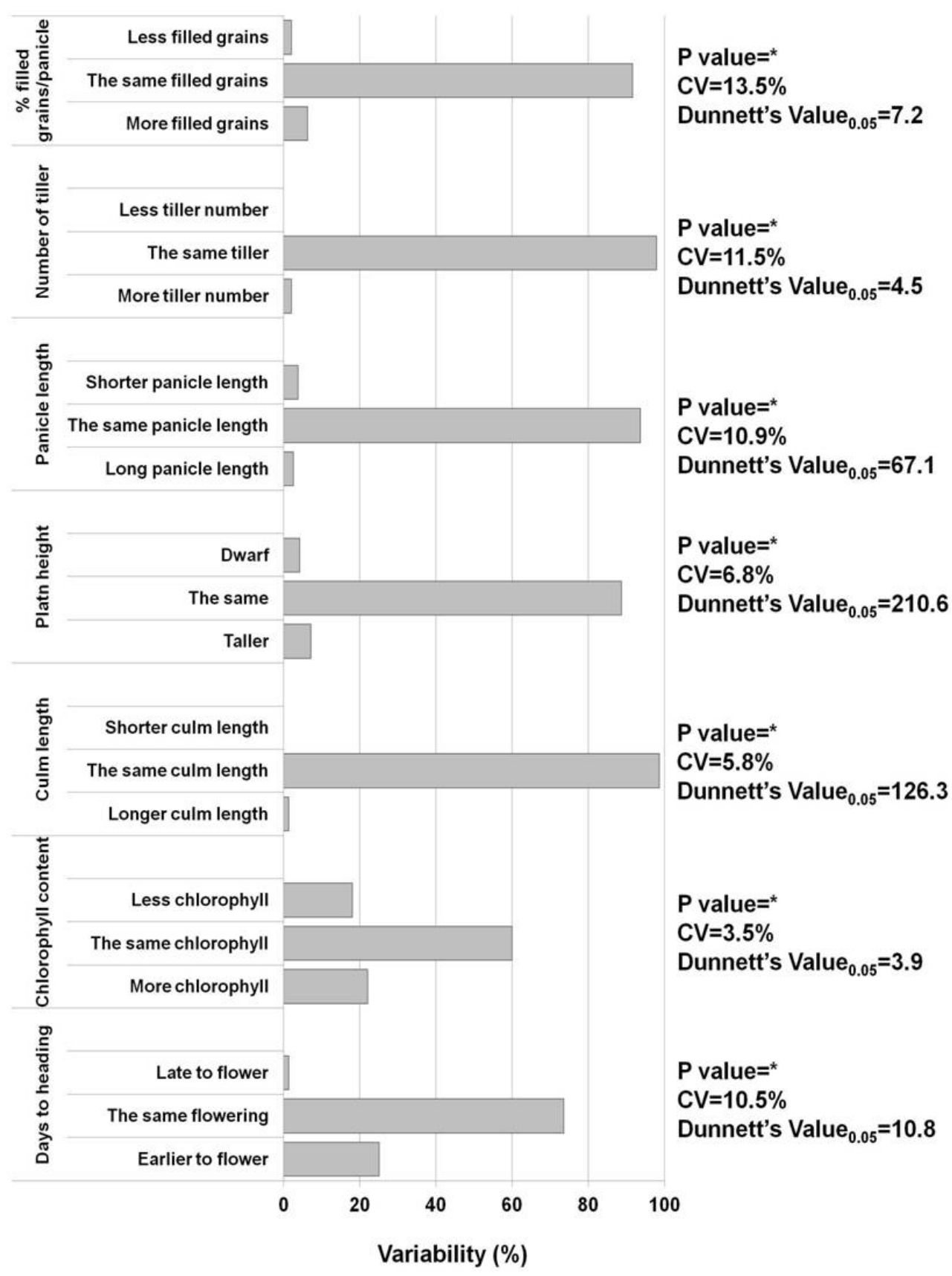

Fig. 6. Morpho-agronomic variability of 1,150 transgenic rice lines. Each transgenic rice line was compared to the wild type Gopum to generate significant differences (positive/negative) by two-pair wise Dunnet's. 


\section{Phenotypic characteristics of the FOX rice lines}

To determine the phenotype of the FOX rice lines, all developed lines were evaluated in the field arranged in an incomplete block design. As shown in Fig. 6, the variability in the number of transgenic lines was significant in each of the agronomic traits measured. Indeed, 25.1\% matured significantly earlier and $22 \%$ contained significantly higher chlorophyll content. Furthermore, 18\% of the transgenic rice lines had lower chlorophyll contents. Other agronomic traits such as filled grains, number of tiller, panicle length, and culm length and plant height showed relatively low variability among lines. All morpho- agronomic traits are recorded. For example, the BR 4 line, which encodes actin-depolymerizing factor 2, exhibited a higher number of tillers. Similarly, BR 119, which encodes a gene with unknown function, gave rise to shorter plants.

The altered agronomic traits observed in the FOX lines may be caused by each gene. Further functional analysis is necessary to determine the function of each gene. Regardless of this, these results provide the basic information required to accelerate future functional studies.
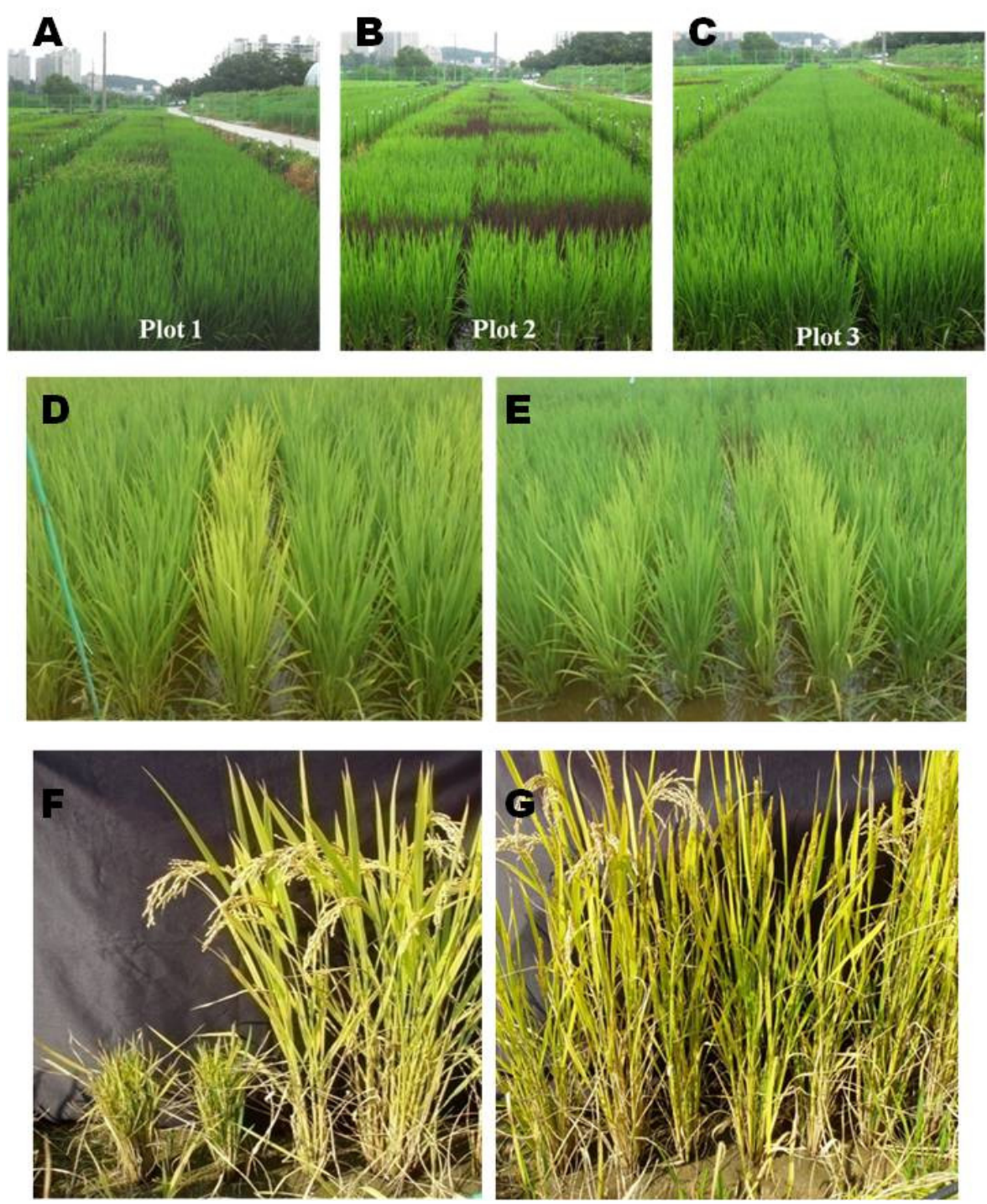

Fig. 7. The field evaluation of transgenic rice. A to $\mathrm{C}$, the field plots of the transgenic lines in the vegetative stage arranged in incomplete block design; D, high senescense observed in BR 73; E, mild senescence in BR61; F, observed dwarf in BR122; G, partial sterility observed in BR 452. 


\section{DISCUSSION}

A total of 1,150 transgenic rice lines with FL-length cDNA genes from Chinese cabbage were generated; these lines contained 250 Brassica rapa FL-cDNAs (Table 4). The size distribution pattern and the average size of FL-cDNAs inserted into the genomes of 250 FOX-rice lines was 900 to $2,100 \mathrm{bp}$ (Fig. 2B). Analyses of individual gene inserts revealed that genes associated with tolerance to cold and salinity were functionally diverse, both at the molecular and biological levels (Fig. 2C). Approximately $1 / 3$ of the gene inserts have no known ascribed function. Furthermore, most of the randomly selected transgenic lines were present as single gene copies (Fig. 3). We overexpressed a variety of transgenes in transgenic rice (Fig. 4). We suggest that our approach will be useful for systematic genome-wide gain-of-function analyses of the Brassica rapa genes that have been inserted into rice.

Phenotypic databases of rice properties have been developed by several groups. These include the International Rice Information System (IRIS) (Wu et al. 2005), Oryzabase (Kurata and Yamazaki 2006), Rice Mutant Database (RMD; Zhang et al. 2006), Rice Tos17 Insertion Mutant Database (Miyao et al. 2007), and Gramene (http://www.gramene.org/). In addition to these useful databases, the transgenic rice lines harboring FL-cDNAs gene from Brassica spp. are expected to provide valuable information for researchers to uncover functions of Brassica genes. Appropriate biological or molecular methodologies are needed to reveal the function of each gene.

We found that $7.9 \%$ of the observed transgenic rice plants showed morpho-agronomically altered phenotypes (Fig. 6). Among the 1,150 transgenic lines, 224 lines (26.4\%) had a significantly altered number of days to heading. Similarly, $40 \%$ had a significant change in the chlorophyll content. Examples of these altered phenotypes are presented in Fig. 7. This rate was much higher than that determined by using activation tagging of rice populations (Jeong et al. 2002). However, for culm length, plant height, panicle length, number of tillers/hill, and percent filled spikelet/panicle, only $3.7 \%$ of transgenic lines were different compared to the wild type. During Agrobacterium transformation, minimal weak growth of the regenerants was observed. This is consistent with a previous report (Nakamura et al. 2007) and underscores the notion that transgenic regenerants often suffer from the effects of environmental factors such as humidity, temperature, macro- and micro-nutrient deficiencies or excesses, and microbes (pathogens), especially in the initial growth stage after transfer to soil. Alternatively, during tissue culture for selection and regeneration of transgenic plants, a variety of both epigenetic (e.g., DNA methylation, gene silencing, activation of retrotransposons and transposable elements) and genetic (e.g., nucleotide substitutions, deletions, insertions, rearrangements) alterations may occur in the plant genome (Kaeppler et al. 2000; Cheng et al. 2006; Noro et al. 2007). These factors, i.e., abiotic and biotic factors and tissue culture-induced variations, may influence the growth conditions to some degree, and consequently, alter the phenotypes of transgenic plants. This may explain the increased rate of phenotype alteration in our transgenic lines (Nakamura et al. 2007).

The response of transgenic rice lines to salinity and cold was tested on 900 independent lines. Eight hundred forty six $(94 \%)$ of the lines were moderately tolerant to the cold stress (Fig. 5A), and 9 lines (1\%) were tolerant. This is not surprising since wild-type Gopum is moderately tolerant to cold stress (Choi et al. 2007). However, most of the transgenic lines (85\%) were highly susceptible to salinity stress (Fig. 5B). Only 5\% were moderately tolerant, and $2 \%$ were tolerant in the transgenic rice lines. In any case, our results have identified possibly agronomically important genes that should be characterized in future studies. Furthermore, manipulation of these genes may lead to improvements in the tolerance parameters of this economically important crop.

The development of full-length cDNA collections is an effective strategy for increasing the catalog of gene transcripts. These data serve as a valuable resource for describing gene expression profiles, and ultimately classify genes into families based on their functions (Abe et al. 2011). Full-length cDNA can also serve as a powerful tool to facilitate genomic or other research (Seki and Shinozaki 2009). Several techniques have been established to prepare enriched full-length cDNA libraries (Seki et al. 1998). The 
utility of full-length cDNAs has been confirmed in various plants, including Arabidopsis (Yang et al. 2006; Alexandrov et al. 2006), rice (Ralph et al. 2008), poplar (Jia et al. 2006), maize (Alexandrov et al. 2009), tomato (Town et al. 2006), and soybean (Umezawa et al. 2008). A major advantage of this approach is that most of the clones contain the complete coding sequence, in addition to the $5^{\prime}$ - and $3^{\prime}$ -untranslated regions.

In this study, we have described the phenotypes and abiotic reactions of individual transgenic rice lines that carry gene inserts isolated from Chinese cabbage. Our results have thus provided a list of potentially economically important genes that can be further studied during future abiotic studies and functional analyses.

\section{ACKNOWLEDGEMENTS}

This work was carried out with the support of Cooperative Research Program for Agriculture Science \& Technology Development (Project No. PJ008529), Rural Development Administration and the research grant of the iPET, Ministry for Food, Agriculture, Forestry and Fisheries, Republic of Korea.

\section{REFERENCES}

Abe H, Narusaka Y, Sasaki I, Hatakeyama K, Shin IS, Narusaka M, Fukami-Kobayashi F, Matsumoto S and Kobayashi M. 2011. Development of full-length cDNAs from chinese cabbage (Brassica rapa Subsp. pekinensis) and identification of marker genes for defence. DNA Research 18:277-289.

Alexandrov NN, Brover VV, Freidin S, Troukhan ME, Tatarinova TV, Zhang H, Swaller TJ, Lu YP, Bouck J, Flavell RB and Feldmann KA. 2009. Insights into corn genes derived from large-scale cDNA sequencing. Plant Mol. Biol. 69:179-194.

Alexandrov NN, Troukhan ME, Brover VV, Tatarinova T, Flavell RB and Feldmann KA. 2006. Features of Arabidopsis genes and genome discovered using full-length cDNAs. Plant Mol. Biol. 60:69-85.

An G, Jeong DH, Jung KH and Lee S. 2005. Reverse genetic approaches for functional genomics of rice. Plant Mol.
Biol. 59:111-123.

Cheng C, Daigen M and Hirochika H. 2006. Epigenetic regulation of the rice retrotransposon Tos 17. Mol. Genet. Genomics 276:378-390.

Cho YG, Kang HJ, Lee JS, Lee YT, Lim SJ, Gauch H, Eun MY and McCouch SR. 2007. Identification of quantitative trait loci in rice for yield, yield components, and agronomic traits across years and locations. Crop Sci. 47:2403-2417.

Choi IS, Kim YG, Cho YC, Hong HC and Baek MK. 2007. A medium-maturing, multi-disease resistant and good eating-quality rice variety "Gopum”. Kor. J. of Plant Breeding Sci. 39:586-587.

Fagard M and Vaucheret H. 2000. (Trans)gene silencing in plants: how many mechanisms? Plant Mol. Biol. 51: 167-174.

Gelvin SB. 2003. Agrobacterium-mediated plant transformation: The biology behind the "gene-jockeying" tool. Microbiol. Mol. Biol. Rev. 67:16-37.

Hirochika H, Guiderdoni E, An G, Hsing YI, Eun MY, Han C, Upadhyaya N, Ramachandran S, Zhang Q, Pereira A, Sundaresan V and Leung H. 2004. Rice mutant resources for gene discovery. Plant Mol. Biol. 54:325-334.

Ichikawa T, Nakazawa M, Kawashima M, Iizumi H, Kuroda H, Kondou Y, Tsuhara Y, Suzuki K, Ishikawa A, Seki M, Fujita M, Motohashi R, Nagata N, Takagi T, Shinozaki K and Matsui M. 2006. The FOX hunting system: an alternative gain-of-function gene hunting technique. Plant J. 48:974-985.

International Rice Genome Sequencing Project (IRGSP). 2005. The map-based sequence of the rice genome. Nature 436:793-800.

International Rice Research Institute (IRRI). 2007. Standard evaluation system for rice. IRRI, Los Baños, Laguna Philippines. p.56

Jeong DH, An S, Kang HG, Moon S, Han JJ, Park S, Lee HS, An K and An G. 2002. T-DNA insertional mutagenesis for activation tagging in rice. Plant Physiol. 130:1636-1644.

Jia J, Fu J, Zheng J, Zhou X, Huai J, Wang J, Wang M, Zhang Y, Chen X, Zhang J, Zhao J, Su Z, Lv Y and Wang G. 2006. Annotation and expression profile analysis of 2073 full-length cDNAs from stress-induced maize. Zea mays L. seedlings. Plant J. 48:710-727.

Kaeppler SM, Kaeppler HF and Rhee Y. 2000. Epigenetic aspects of somaclonal variation in plants. Plant Mol. Biol. 43:179-188.

Karlowski WM, Schoof H, Janakiraman V, Stuempflen V and 
Mayer KF. 2003. MOsDB: an integrated information resource for rice genomics. Nucleic Acids Res. 31:190-192.

Kurata N and Yamazaki Y. 2006. Oryzabase: an integrated biological and genome information database for rice. Plant Physiol. 140:12-17.

Lee HJ, Abdula SE, Jee MG, Jang DW and Cho YG. 2011. High-efficiency and Rapid Agrobacterium-mediated genetic transformation method using germinating rice seeds. J. Plant Biotechnol. 38:251-257.

Manigbas NL, Park DS, Park SK, Han SI, Park HM, Hwang WH, Kim SM, Wang HJ, Kang HW, Kim DH, Yun DJ and Yi GW. 2011. Enhanced tolerance of transgenic rice overexpressing Arabidopsis thaliana nucleoside diphosphate kinase (AtNDPK2) against various environmental stresses. Philipp. Agric. Scientist 94:29-37.

Marathe R, Anandalakshm R, Smith TH, Pruss GJ and Vance VB. 2000. RNA viruses as inducers, suppressors and targets of post-transcriptional gene silencing. Plant Mol. Biol. 43:295-306.

Miyao A, Iwasaki Y, Kitano H, Itoh J, Maekawa M, Murata K, Yatou O, Nagato Y and Hirochika H. 2007. A large-scale collection of phenotypic data describing an insertional mutant population to facilitate functional analysis of rice genes. Plant Mol. Biol. 63:625-635.

Nakamura H, Hakata M, Amano K, Miyao A, Toki N, Kajikawa M, Pang J, Higashi N, Ando S, Toki S, Fujita M, Enju A, Seki M, Nakazawa M, Ichikawa T, Shinozaki K, Matsui M, Nagamura Y, Hirochika $\mathrm{H}$ and Ichikawa $\mathrm{H}$. 2007. A genome-wide gain-of-function analysis of rice genes using the FOX-hunting system. Plant Mol. Biol. 65:357-371.

Noro Y, Takano-Shimizu T, Syono K, Kishima Y and Sano Y. 2007. Genetic variations in rice in vitro cultures at the EPSPs-RPS20 region. Theor. Appl. Genet. 114: 705-711.

Ohyanagi H, Tanaka T, Sakai H, Shigemoto Y, Yamaguchi K, Habara T, Fujii Y, Antonio BA, Nagamura Y, Imanishi T, Ikeo K, Itoh T, Gojobori T and Sasaki T. 2006. The rice annotation project database (RAP-DB): hub for Oryza sativa ssp. japonica genome information. Nucleic Acids Res. 34:741-744.

Ouyang S, Zhu W, Hamilton J, Lin H, Campbell M, Childs K, Thibaud-Nissen F, Malek RL, Lee Y, Zheng L, Orvis J, Haas B, Wortman J and Buell CR. 2007. The TIGR rice genome annotation resource: improvements and new features. Nucleic Acids Res. 35:883-887.

Ralph SG, Chun HJE, Cooper D, Kirkpatrick R, Kolosova N, Gunter L, Tuskan GA, Douglas CJ, Holt RA, Jones SJM,
Marra MA and Bohlmann J. 2008. Analysis of 4,664 high-quality sequence-finished poplar full length cDNA clones and their utility for the discovery of genes responding to insect feeding. BMC Genomics 9:57.

Rice Annotation Project. 2007. Curated genome annotation of Oryza sativa ssp. japonica and comparative genome analysis with Arabidopsis thaliana. Genome Res. 17: 175-183.

Sasaki T, Matsumoto T, Antonio BA and Nagamura Y. 2005. From mapping to sequencing, post-sequencing and beyond. Plant Cell Physiol. 46:3-13.

Schrider DR and Hahn MW. 2010. Gene copy-number polymorphism in nature. Proc. Biol. Sci. 277:3213-3221.

Seki M, Narusaka M, Kamiya A, Ishida J, Satou M, Sakurai T, Nakajima M, Enju A, Akiyama K, Oono Y, Muramatsu M, Hayashizaki Y, Kawai J, Carninci P, Itoh M, Ishii Y, Arakawa T, Shibata K, Shinagawa A and Shinozaki K. 2002. Functional annotation of a full-length Arabidopsis cDNA collection. Science 296:141-145.

Seki M, Carninci P, Nishiyama Y, Hayashizaki Y and Shinozaki K. 1998. High-efficiency cloning of Arabidopsis full-length cDNA by biotinylated CAP trapper. Plant J. 15:707-720.

Seki M and Shinozaki K. 2009. Functional genomics using RIKEN Arabidopsis thaliana full-length cDNAs. J. Plant Res. 122:355-366.

Sun MM, Abdula SE, Lee HY, Cho YC, Han LZ, Koh HJ and Cho YG. 2011. Molecular aspect of good eating quality formation in japonica rice. PLoS ONE 6(4): e18385. doi:10.1371/journal.pone. 0018385.

Toki S, Hara N, Ono K, Onodera H, Tagiri A, Oka S and Tanaka H. 2006. Early infection of scutellum tissue with Agrobacterium allows high-speed transformation of rice. Plant J. 47:969-976.

Town CD, Cheung F, Maiti R, Crabtree J, Haas BJ, Wortman JR, Hine EE, Althoff R, Arbogast TS, Tallon LJ, Vigouroux M, Trick M and Bancroft I. 2006. Comparative genomics of Brassica oleracea and Arabidopsis thaliana reveal gene loss, fragmentation, and dispersal after polyploidy. Plant Cell 18:1348-1359.

Umezawa T, Sakurai T and Totoki Y. 2008. Sequencing and analysis of approximately 40,000 soybean cDNA clones from a full-length-enriched cDNA library. DNA Res. 15:333-346.

Vaucheret H and Fagard M. 2001. Transcriptional gene silencing in plants: targets, inducers and regulators. TRENDS in Genetics 17:29-34. 
Wu JL, Wu C, Lei C, Baraoidan M, Bordeos A, Madamba MR, Ramos-Pamplona M, Mauleon R, Portugal A, Ulat VJ, Bruskiewich R, Wang G, Leach J, Khush G and Leung H. 2005. Chemical and irradiation-induced mutants of indica rice IR64 for forward and reverse genetics. Plant Mol. Biol. 59:85-97.

Yang TJ, Kim JS, Kwon SJ, Lim KB, Choi BS, Kim JA and Jin M. 2006. Sequence-level analysis of the diploidization process in the triplicated FLOWERING LOCUS C region of Brassica rapa. Plant Cell 18: 1339-1347.
Zhang J, Li C, Wu C, Xiong L, Chen G, Zhang Q and Wang S. 2006. RMD: a rice mutant database for functional analysis of the rice genome. Nucleic Acids Res. 34: 745-748.

Zhao W, Wang J, He X, Huang X, Jiao Y, Dai M, Wei S, Fu J, Chen Y, Ren X, Zhang Y, Ni P, Zhang J, Li S, Wang J, Wong GK, Zhao H, Yu J, Yang H and Wang J. 2004. BGI-RIS: an integrated information resource and comparative analysis workbench for rice genomics. Nucleic Acids Res. 32:377-382. 
Appendix Table 1. List of transgenic rice with full-length cDNA from B. rapa, its annotation function and their morphoagronomic traits.

\begin{tabular}{|c|c|c|c|c|}
\hline Code & Gene Function & $\begin{array}{c}\text { Cold } \\
\text { stress score }\end{array}$ & $\begin{array}{c}\text { Salinity } \\
\text { stress score }\end{array}$ & Observed phenotype $^{c}$ \\
\hline BR 2 & cysteine protease 1 & 5.7 & 9.0 & more green leaves \\
\hline BR 4 & ADF2 (Actin depolymerizing factor 2) & 5.0 & 9.0 & more number of tiller \\
\hline BR 5 & PsbQ2 mRNA for oxygen-evolving enhancer protein 3-2 & 3.0 & 9.0 & more green leaves \\
\hline BR 6 & Zea mays clone 93807 mRNA sequence & 5.0 & 9.0 & more green leaves \\
\hline BR 7 & Dead box RNA helicase RH15 - like protein & 3.0 & 3.0 & same phenotype \\
\hline BR 9 & PEC-1 mRNA for Lipid transfer protein & 5.0 & 9.0 & more green leaves \\
\hline BR 12 & Rac GTPase activator & 5.0 & 9.0 & same phenotype \\
\hline BR 14 & CBL-interacting protein kinase 3 & 5.2 & 5.5 & less green leaves \\
\hline BR 17 & mRNA for aluminum-induced & 5.0 & 9.0 & less green leaves \\
\hline BR 23 & endoplasmic reticulum auxin-binding protein 2 & 9.0 & 7.0 & less green leaves \\
\hline BR 26 & $\begin{array}{l}\text { Brassica rapa subsp. pekinensis clone } \mathrm{KBrH} 004 \mathrm{~A} 06 \text {, } \\
\text { complete sequence }\end{array}$ & 5.3 & 9.0 & same phenotype \\
\hline BR 29 & Phospholipase C & 5.2 & 7.0 & less green leaves \\
\hline BR 33 & $\mathrm{ABC}$ transporter-like protein & 9.0 & 9.0 & less green leaves \\
\hline BR 37 & CBL-interacting protein kinase 1 & 5.4 & 3.0 & $\begin{array}{l}\text { less green leaves, less plant } \\
\text { height }\end{array}$ \\
\hline BR 39 & carbohydrate binding & 4.3 & 9.0 & less green leaves \\
\hline BR 40 & protein phosphatase $2 \mathrm{C}$, putative / $\mathrm{PP} 2 \mathrm{C}$ & 4.7 & 3.0 & $\begin{array}{l}\text { less green leaves, shorter } \\
\text { culm length }\end{array}$ \\
\hline BR 46 & plasma membrane intrinsic protein $2(P I P 2)$ & 5.0 & 9.0 & $\begin{array}{l}\text { less green leaves, more } \\
\text { taller }\end{array}$ \\
\hline BR 48 & senescence-associated cysteine protease (CP1) & 4.8 & 5.0 & more number of tiller \\
\hline BR 49 & polypeptide of photosystem II reaction center & 9.0 & 9.0 & less green leaves \\
\hline BR 50 & chlorophyll $\mathrm{a} / \mathrm{b}$ binding protein & & 9.0 & less green leaves \\
\hline BR 51 & methyl-CpG-binding domain 4 (MBD4) & 9.0 & 9.0 & $\begin{array}{l}\text { less green leaves, longer } \\
\text { panicle length }\end{array}$ \\
\hline BR 57 & putative protein transport protein SEC61 alpha subunit & 5.0 & 7.0 & less green leaves \\
\hline BR 60 & $\begin{array}{l}\text { Brassica rapa subsp. pekinensis clone } \mathrm{KBrB} 042 \mathrm{D} 24 \text {, } \\
\text { complete sequence }\end{array}$ & 5.0 & 9.0 & less green leaves \\
\hline BR 61 & rubredoxin family protein & 6.0 & 9.0 & less green leaves \\
\hline BR 64 & GDSL esterase/lipase APG & 5.0 & 9.0 & $\begin{array}{l}\text { less green leaves, longer } \\
\text { panicle length, Shorter } \\
\text { culm length }\end{array}$ \\
\hline BR 72 & $\begin{array}{l}\text { WSCP1 mRNA for water-soluble chlorophyll protein } \\
\text { precursor }\end{array}$ & 5.0 & 9.0 & same phenotype \\
\hline BR 73 & unknown protein & 6.0 & 9.0 & less green leaves \\
\hline BR 74 & haloacid dehalogenase-like hydrolase family protein & 5.0 & 3.0 & $\begin{array}{l}\text { less green leaves, more } \\
\text { number of tiller }\end{array}$ \\
\hline BR81 & regulatory subunit of protein kinase $\mathrm{CK} 2$ & 5.0 & 7.0 & $\begin{array}{l}\text { less green leaves, shorter } \\
\text { culm length }\end{array}$ \\
\hline BR 84 & ATCTIMC (Cytosolic triose phosphate isomerase) & 5.0 & 9.0 & shorter culm length \\
\hline BR 89 & $\begin{array}{l}\text { Brassica rapa subsp. pekinensis clone KBrH004P05, } \\
\text { complete sequence }\end{array}$ & 5.7 & 9.0 & same phenotype \\
\hline
\end{tabular}


Appendix Table 1. Continued.

\begin{tabular}{|c|c|c|c|c|}
\hline Code & Gene Function & $\begin{array}{l}\text { Cold } \\
\text { stress score }^{a}\end{array}$ & $\begin{array}{l}\text { Salinity } \\
\text { stress score }^{b}\end{array}$ & Observed phenotype $^{\mathrm{c}}$ \\
\hline BR 91 & unknown protein & 5.2 & 3.0 & $\begin{array}{l}\text { less green leaves, longer } \\
\text { culm length }\end{array}$ \\
\hline BR 92 & 5-enolpyruvylshikimate-3-phosphate synthase (EPSP) & 5.0 & 9.0 & same phenotype \\
\hline BR 97 & G6PD1 (glucose-6-phosphate dehydrogenase 1) & 5.1 & 9.0 & same phenotype \\
\hline BR 99 & 40S ribosomal protein S7 (RPS7C) & 5.0 & 9.0 & same phenotype \\
\hline BR 104 & protein binding / zinc ion binding & 5.0 & 9.0 & same phenotype \\
\hline BR 105 & Lhcb6 protein mRNA & 5.0 & 9.0 & more number of tiller \\
\hline BR 111 & protein kinase family protein & 5.0 & 9.0 & same phenotype \\
\hline BR 112 & $\begin{array}{l}\text { Arabidopsis thaliana AT5g47540/MNJ7_13 mRNA, } \\
\text { complete cds }\end{array}$ & 5.0 & 9.0 & same phenotype \\
\hline BR 113 & $\begin{array}{l}\text { Brassica rapa subsp. pekinensis clone } \mathrm{KBrB} 052 \mathrm{~L} 10 \text {, } \\
\text { complete sequence }\end{array}$ & 5.8 & 9.0 & same phenotype \\
\hline BR 114 & Zea mays clone 13119 mRNA sequence & 5.0 & 9.0 & less plant height \\
\hline BR 115 & Arabidopsis thaliana At5g25810 mRNA, complete cds & 3.0 & 9.0 & same phenotype \\
\hline BR 116 & Unknown & 5.0 & 9.0 & same phenotype \\
\hline BR 118 & $\begin{array}{l}\text { Vitis vinifera, whole genome shotgun sequence, contig } \\
\text { VV78X164547.5, clone ENTAV } 115\end{array}$ & 6.0 & 9.0 & same phenotype \\
\hline BR 119 & unknown protein & 3.0 & 3.0 & shorter plant height \\
\hline BR 120 & Zea mays clone 14950 mRNA sequence & 5.0 & 6.2 & same phenotype \\
\hline BR 122 & DNAJ heat shock N-terminal domain-containing protein & 5.0 & 9.0 & same phenotype \\
\hline BR 124 & putative thioredoxin reductase & 4.8 & 9.0 & same phenotype \\
\hline BR 125 & $\begin{array}{l}\text { Brassica rapa subsp. pekinensis clone KBrS004A14, } \\
\text { complete sequence }\end{array}$ & 5.0 & 9.0 & less plant height \\
\hline BR 128 & Zea mays clone 9139 mRNA sequence & 5.0 & 9.0 & same phenotype \\
\hline BR 129 & dimethylmenaquinone methyltransferase family protein & 5.0 & 9.0 & same phenotype \\
\hline BR133 & prephenate dehydratase family protein & 5.0 & 9.0 & same phenotype \\
\hline BR139 & 231 CLA1-like protein mRNA & 5.1 & 9.0 & same phenotype \\
\hline BR147 & 231 CLA1-like protein mRNA & 5.0 & 9.0 & same phenotype \\
\hline BR148 & $\begin{array}{l}\text { protein kinase family protein / C-type lectin } \\
\text { domain-containing protein }\end{array}$ & 5.0 & 5.2 & same phenotype \\
\hline BR 149 & XTR4 (xyloglucan endotransglycolase 4) & 5.0 & 9.0 & same phenotype \\
\hline BR 151 & clathrin adaptor complexes medium subunit-related & 5.0 & 9.0 & same phenotype \\
\hline BR 152 & unknown mRNA & 5.0 & 9.0 & same phenotype \\
\hline BR 158 & unknown protein (AT1G34010) mRNA & 5.0 & 9.0 & same phenotype \\
\hline BR 160 & SCL5; transcription factor (SCL5) & 5.0 & 5.8 & same phenotype \\
\hline BR162 & $\begin{array}{l}\text { Brassica rapa subsp. pekinensis clone KBrB005N03, } \\
\text { complete sequence }\end{array}$ & 5.0 & 9.0 & same phenotype \\
\hline BR 165 & $\begin{array}{l}\text { Arabidopsis thaliana genomic DNA, chromosome 5, P1 } \\
\text { clone:MZN1 }\end{array}$ & 5.0 & 9.0 & more number of tiller \\
\hline BR 171 & $\begin{array}{l}\text { Brassica rapa subsp. pekinensis clone } \mathrm{KBrH} 004 \mathrm{~A} 18 \text {, } \\
\text { complete sequence }\end{array}$ & 5.5 & 9.0 & more number of tiller \\
\hline BR 173 & BSD domain-containing protein & 4.7 & 9.0 & same phenotype \\
\hline
\end{tabular}


Appendix Table 1. Continued.

\begin{tabular}{|c|c|c|c|c|}
\hline Code & Gene Function & $\begin{array}{l}\text { Cold } \\
\text { stress score }^{\mathrm{a}}\end{array}$ & $\begin{array}{l}\text { Salinity } \\
\text { stress score }^{b}\end{array}$ & Observed phenotype ${ }^{\mathrm{c}}$ \\
\hline BR 174 & $\begin{array}{l}\text { SEC14 cytosolic factor family protein / phosphoglyceride } \\
\text { transfer family protein }\end{array}$ & 5.5 & 9.0 & same phenotype \\
\hline BR 178 & unknown protein & 4.0 & 9.0 & same phenotype \\
\hline BR 179 & Zea mays clone 8974 mRNA sequence & 5.5 & 5.6 & same phenotype \\
\hline BR 192 & glycosyltransferase family protein & 5.0 & 9.0 & same phenotype \\
\hline BR 195 & ASP2 (aspartate aminotransferase $2(A S P 2)$ & 5.7 & 9.0 & same phenotype \\
\hline BR 225 & unknown & 5.0 & 9.0 & same phenotype \\
\hline BR 240 & $\begin{array}{l}\text { Brassica rapa subsp. pekinensis clone } \mathrm{KBrH} 080 \mathrm{C} 09 \text {, } \\
\text { complete sequence }\end{array}$ & 5.0 & 9.0 & same phenotype \\
\hline BR 246 & CTR1 (constitutive triple response 1 & 5.0 & 9.0 & same phenotype \\
\hline BR 250 & unknown protein & 5.0 & 9.0 & same phenotype \\
\hline BR 255 & Indole-3-glycerol phosphate synthase & 5.5 & 9.0 & same phenotype \\
\hline BR 256 & leucine-rich repeat transmembrane protein kinase & 5.0 & 9.0 & same phenotype \\
\hline BR 257 & Unknown & 5.0 & 9.0 & same phenotype \\
\hline BR 261 & $\begin{array}{l}\text { Arabidopsis thaliana Full-length cDNA Complete sequence } \\
\text { from clone GSLTSIL12ZB10 of Silique of strain col-0 of } \\
\text { Arabidopsis thaliana (thale cress) }\end{array}$ & 5.0 & 9.0 & same phenotype \\
\hline BR 262 & Glycosyl hydrolase family 17 protein & 4.8 & 9.0 & same phenotype \\
\hline BR 263 & $\begin{array}{l}\text { CA2 (beta carbonic anhydrase 2); carbonate dehydratase/ } \\
\text { zinc ion binding (CA2) }\end{array}$ & 5.0 & 9.0 & longer panicle length \\
\hline BR 264 & Eukaryotic translation initiation factor $1 \mathrm{~A}$ & 5.0 & 9.0 & same phenotype \\
\hline BR 265 & Zea mays clone 11869 mRNA sequence & 5.0 & 9.0 & shorter plant height \\
\hline BR 271 & rhodanese-like domain-containing protein & 5.0 & 9.0 & same phenotype \\
\hline BR 273 & WD-40 repeat family protein & 5.0 & 9.0 & same phenotype \\
\hline BR 274 & $\begin{array}{l}\text { Brassica rapa subsp. pekinensis clone KBrH006E } 24 \text {, } \\
\text { complete sequence }\end{array}$ & 5.0 & 9.0 & same phenotype \\
\hline BR 275 & pentatricopeptide (PPR) repeat-containing protein & 5.0 & 6.0 & same phenotype \\
\hline BR 293 & Zea mays clone 11032 mRNA sequence & 4.0 & 9.0 & same phenotype \\
\hline BR 303 & nodulin family protein & 5.0 & 9.0 & same phenotype \\
\hline BR 305 & Unknown protein & 5.0 & 9.0 & same phenotype \\
\hline BR 308 & Zea mays clone 15053 mRNA sequence & 4.9 & 9.0 & same phenotype \\
\hline BR 311 & Actin (Act1) mRNA & 5.0 & 9.0 & same phenotype \\
\hline BR 318 & unknown protein & 5.4 & 9.0 & same phenotype \\
\hline BR 319 & aldehyde dehydrogenase & 5.0 & 9.0 & same phenotype \\
\hline BR 322 & unknown protein & 5.0 & 9.0 & same phenotype \\
\hline BR 336 & unknown protein & 5.0 & 9.0 & same phenotype \\
\hline BR 323 & unknown protein & 5.0 & 9.0 & same phenotype \\
\hline BR 330 & unknown protein & 5.0 & 9.0 & same phenotype \\
\hline BR 336 & unknown protein & 5.0 & 9.0 & shorter plant height \\
\hline BR 339 & HDA6 (histone deacetylase 6) & 5.0 & 9.0 & shorter plant height \\
\hline BR 343 & $\begin{array}{l}\text { ATNUDT2 (Arabidopsis thaliana Nudix hydrolase homolog } \\
\text { 2); ADP-ribose diphosphatase/ NAD binding / hydrolase } \\
(\text { ATNUDT2) mRNA, complete cds }\end{array}$ & 5.0 & 9.0 & same phenotype \\
\hline
\end{tabular}


Appendix Table 1. Continued.

\begin{tabular}{|c|c|c|c|c|}
\hline Code & Gene Function & $\begin{array}{l}\text { Cold } \\
\text { stress score }^{\mathrm{a}}\end{array}$ & $\begin{array}{l}\text { Salinity } \\
\text { stress score }^{b}\end{array}$ & Observed phenotype $^{c}$ \\
\hline BR 348 & ELO1 (elongate 1) mRNA & 5.0 & 9.0 & $\begin{array}{l}\text { more green leaves, shorter } \\
\text { plant height }\end{array}$ \\
\hline BR 349 & unknown protein & 5.0 & 6.0 & same phenotype \\
\hline BR 367 & unknown gene function & 4.8 & 9.0 & same phenotype \\
\hline BR 368 & $\begin{array}{l}\text { ribulose 1,5-bisphosphate carboxylase/oxygenase small } \\
\text { subunit }\end{array}$ & 5.0 & 9.0 & more green leaves \\
\hline BR 369 & 60S ribosomal protein L10A (RPL10aC) & 5.0 & 9.0 & same phenotype \\
\hline BR 370 & tubulin-specific chaperone C-related & 5.0 & 9.0 & same phenotype \\
\hline BR 374 & $\mathrm{ABC} 1$ family protein & 5.0 & 9.0 & same phenotype \\
\hline BR 375 & Zea mays clone 13431 mRNA sequence & 5.5 & 9.0 & same phenotype \\
\hline BR 376 & transcriptional repressor & 5.0 & 9.0 & same phenotype \\
\hline BR 377 & $\begin{array}{l}\text { Arabidopsis thaliana clone } 37944 \text { mRNA, complete } \\
\text { sequence }\end{array}$ & 5.0 & 9.0 & same phenotype \\
\hline BR 383 & CLA1-like protein mRNA & 5.0 & 9.0 & same phenotype \\
\hline BR 384 & unknown protein & 5.0 & 9.0 & shorter plant height \\
\hline BR 386 & 60S ribosomal protein L28 (RPL28C) & 5.0 & 9.0 & $\begin{array}{l}\text { less green leaves, shorter } \\
\text { plant height }\end{array}$ \\
\hline BR 393 & unknown protein & 5.5 & 9.0 & same phenotype \\
\hline BR 418 & WNK1 (WITH NO LYSINE (K) 1); kinase (WNK1) mRNA & 5.2 & 9.0 & same phenotype \\
\hline BR 425 & $\begin{array}{l}\text { Brassica rapa subsp. pekinensis clone } \mathrm{KBrH} 080 \mathrm{C} 09 \text {, } \\
\text { complete sequence }\end{array}$ & 5.5 & 9.0 & $\begin{array}{l}\text { shorter plant height, longer } \\
\text { panicle length }\end{array}$ \\
\hline BR 436 & putative nuclear transport factor 2 mRNA & 5.0 & 9.0 & same phenotype \\
\hline BR 438 & $60 \mathrm{~S}$ acidic ribosomal protein $\mathrm{P} 0$ (RPP0B) & 5.0 & 9.0 & same phenotype \\
\hline BR 445 & transporter-related & 5.0 & 9.0 & more green leaves \\
\hline BR 449 & $\begin{array}{l}\text { FTSH8 (FtsH protease 8); ATP-dependent peptidase/ } \\
\text { ATPase/ metallopeptidase/ zinc ion binding (FTSH8) } \\
\text { mRNA }\end{array}$ & 5.0 & 6.9 & same phenotype \\
\hline BR 450 & $\begin{array}{l}\text { Brassica rapa subsp. pekinensis clone } \mathrm{KBrS} 015 \mathrm{~K} 01 \text {, } \\
\text { complete sequence }\end{array}$ & 5.0 & 9.0 & more green leaves \\
\hline BR 452 & nuclear transport factor 2 mRNA & 5.2 & 9.0 & more green leaves \\
\hline BR 499 & $\begin{array}{l}\text { Brassica rapa subsp. pekinensis clone } \mathrm{KBrH} 003 \mathrm{~N} 18 \text {, } \\
\text { complete sequence }\end{array}$ & 5.0 & 7.0 & same phenotypE \\
\hline BR467 & $\begin{array}{l}\text { Arabidopsis thaliana PTAC16 (PLASTID } \\
\text { TRANSCRIPTIONALLY ACTIVE 16); binding / catalytic } \\
\text { (PTAC16) mRNA, complete cds }\end{array}$ & 5.0 & 9.0 & same phenotype \\
\hline BR 468 & $\begin{array}{l}\text { Brassica rapa subsp. pekinensis clone } \mathrm{KBrB} 034 \mathrm{~N} 10 \text {, } \\
\text { complete sequence }\end{array}$ & 5.0 & 9.0 & more green leaves \\
\hline BR 471 & Arabidopsis lyrata subsp. lyrata hypothetical protein, mRNA & 5.0 & 9.0 & same phenotype \\
\hline BR 470 & B-box type zinc finger protein (Bbox1) mRNA & 9.0 & 9.0 & more number of tiller \\
\hline BR 472 & $\begin{array}{l}\text { Brassica rapa subsp. pekinensis clone } \mathrm{KBrB} 028 \mathrm{I} 01 \text {, } \\
\text { complete sequence }\end{array}$ & 5.0 & 6.4 & same phenotype \\
\hline BR 473 & Zea mays clone 17728 mRNA sequence & 5.0 & 9.0 & shorter culm length \\
\hline BR 474 & ACC oxidase (ACC0x2) & 5.0 & 9.0 & same phenotype \\
\hline
\end{tabular}


Appendix Table 1. Continued.

\begin{tabular}{|c|c|c|c|c|}
\hline Code & Gene Function & $\begin{array}{l}\text { Cold } \\
\text { stress score }^{a}\end{array}$ & $\begin{array}{l}\text { Salinity } \\
\text { stress score }^{b}\end{array}$ & Observed phenotype $^{c}$ \\
\hline BR 475 & Zea mays clone 17728 mRNA sequence & 5.0 & 9.0 & more taller plant height \\
\hline BR 478 & unknown protein & 5.0 & 9.0 & same phenotype \\
\hline BR 479 & $\begin{array}{l}\text { Brassica rapa subsp. pekinensis clone KBrB021M22, } \\
\text { complete sequence }\end{array}$ & 5.0 & 9.0 & same phenotype \\
\hline BR 480 & $\begin{array}{l}\text { Arabidopsis thaliana unknown protein (AT3G18050) } \\
\text { mRNA }\end{array}$ & 5.0 & 9.0 & same phenotype \\
\hline BR 481 & $\begin{array}{l}\text { AL5 (ALFIN-LIKE 5); DNA binding / methylated histone } \\
\text { residue binding (AL5) }\end{array}$ & 5.0 & 9.0 & same phenotype \\
\hline BR 482 & $\begin{array}{l}\text { Arabidopsis thaliana LHCB3 (LIGHT-HARVESTING } \\
\text { CHLOROPHYLL B-BINDING PROTEIN 3); structural } \\
\text { molecule (LHCB3) mRNA, complete cds }\end{array}$ & 5.0 & 9.0 & $\begin{array}{l}\text { more green leaves, longer } \\
\text { panicle length }\end{array}$ \\
\hline BR 482 & unknown protein & 5.0 & 9.0 & more green leaves \\
\hline BR 484 & Zea mays clone 12745 mRNA sequence & 5.0 & 9.0 & same phenotype \\
\hline BR 486 & $\begin{array}{l}\text { Arabidopsis thaliana LHCB3 (LIGHT-HARVESTING } \\
\text { CHLOROPHYLL B-BINDING PROTEIN 3); structural } \\
\text { molecule (LHCB3) mRNA, complete cds }\end{array}$ & 5.0 & 9.0 & same phenotype \\
\hline BR 487 & $\begin{array}{l}\text { Brassica rapa subsp. pekinensis clone KBrB021M22, } \\
\text { complete sequence }\end{array}$ & 5.0 & 9.0 & same phenotype \\
\hline BR 488 & unknown gene function & 5.7 & 9.0 & more green leaves \\
\hline BR 489 & $\begin{array}{l}\text { Arabidopsis thaliana 60S ribosomal protein L13 (RPL13D) } \\
\text { (AT5G23900) mRNA, complete cds }\end{array}$ & 5.0 & 9.0 & more green leaves \\
\hline BR 490 & short-chain dehydrogenase/reductase (SDR) family protein & 5.0 & 9.0 & more green leaves \\
\hline BR 491 & $\begin{array}{l}\text { transducin family protein / WD- } 40 \text { repeat family protein } \\
\text { (AT2G16405) mRNA }\end{array}$ & 5.0 & 9.0 & same phenotype \\
\hline BR 492 & $\begin{array}{l}\text { Phagocytosis and cell motility protein ELMO1-related } \\
\text { (AT3G03610) mRNA }\end{array}$ & 5.0 & 9.0 & same phenotype \\
\hline BR 494 & HD2C (HISTONE DEACETYLASE 2C) & 5.0 & 9.0 & same phenotype \\
\hline BR 495 & unknown protein & 5.1 & 9.0 & same phenotype \\
\hline BR 496 & unknown gene function & 5.0 & 9.0 & shorter culm length \\
\hline BR 497 & unknown gene function & 5.0 & 9.0 & same phenotype \\
\hline BR 498 & unknown protein & 5.0 & 9.0 & same phenotype \\
\hline BR 499 & $\begin{array}{l}\text { Brassica rapa subsp. pekinensis clone } \mathrm{KBrH} 003 \mathrm{~N} 18 \text {, } \\
\text { complete sequence }\end{array}$ & 5.0 & 9.0 & same phenotype \\
\hline BR 485 & $\begin{array}{l}\text { Arabidopsis thaliana unknown protein (At1g15180) } \\
\text { mRNA, complete cds / MATE efflux family protein } \\
\text { [Arabidopsis thaliana] }\end{array}$ & 5.0 & 9.0 & shorter culm length \\
\hline BR 500 & $\begin{array}{l}\text { Arabidopsis lyrata subsp. lyrata hypothetical protein, } \\
\text { mRNA }\end{array}$ & 5.1 & 9.0 & same phenotype \\
\hline BR 501 & $\begin{array}{l}\text { Brassica rapa subsp. pekinensis clone KBrB030F } 12 \text {, } \\
\text { complete sequence }\end{array}$ & 5.0 & 9.0 & same phenotype \\
\hline BR 502 & $\begin{array}{l}\text { Brassica oleracea var. botrytis tonoplast intrinsic protein } \\
\text { bobTIP26-1 mRNA, complete cds }\end{array}$ & 5.0 & 9.0 & same phenotype \\
\hline BR 503 & metal tolerance protein 5 (MTP5) & 5.0 & 9.0 & same phenotype \\
\hline BR 504 & $\begin{array}{l}\text { Brassica rapa subsp. pekinensis clone } \mathrm{KBrH} 003 \mathrm{~N} 18 \text {, } \\
\text { complete sequence }\end{array}$ & 5.0 & 9.0 & same phenotype \\
\hline
\end{tabular}


Appendix Table 1. Continued.

\begin{tabular}{|c|c|c|c|c|}
\hline Code & Gene Function & $\begin{array}{l}\text { Cold } \\
\text { stress score }^{\mathrm{a}}\end{array}$ & $\begin{array}{l}\text { Salinity } \\
\text { stress score }^{\mathrm{b}}\end{array}$ & Observed phenotype \\
\hline BR 505 & Brassica napus 1433-3 mRNA, complete cds & 5.0 & 9.0 & same phenotype \\
\hline BR 506 & $\begin{array}{l}\text { Brassica oleracea var. botrytis tonoplast intrinsic protein } \\
\text { bobTIP26-1 mRNA, complete cds }\end{array}$ & 5.0 & 9.0 & shorter culm length \\
\hline BR 507 & $\begin{array}{l}\text { Arabidopsis thaliana } 60 \mathrm{~S} \text { ribosomal protein L21 (RPL21C) } \\
\text { (AT1G09690) mRNA, complete cds }\end{array}$ & 5.0 & 9.0 & shorter culm length \\
\hline BR 508 & $\begin{array}{l}\text { Arabidopsis thaliana BOU (A BOUT DE SOUFFLE); } \\
\text { binding / transporter (BOU) mRNA, complete cds }\end{array}$ & 5.0 & 9.0 & same phenotype \\
\hline BR 509 & $\begin{array}{l}\text { Arabidopsis thaliana ING1 (INHIBITOR OF GROWTH } \\
\text { 1); DNA binding / methylated histone residue binding } \\
\text { (ING1) mRNA, complete cds }\end{array}$ & 5.0 & 9.0 & same phenotype \\
\hline BR 510 & hypothetical protein & 5.0 & 9.0 & shorter culm length \\
\hline BR 511 & $\begin{array}{l}\text { VHS domain-containing protein / GAT domain-containing } \\
\text { protein }\end{array}$ & 5.3 & 9.0 & same phenotype \\
\hline BR 512 & RsGGT2 mRNA for gamma-glutamyl transferase & 5.0 & 9.0 & same phenotype \\
\hline BR 513 & hypothetical protein & 4.5 & 5.0 & same phenotype \\
\hline BR 514 & $\begin{array}{l}\text { Arabidopsis thaliana clone } 25991 \text { mRNA, complete } \\
\text { sequence }\end{array}$ & 5.0 & 9.0 & same phenotype \\
\hline BR 515 & Prephenate dehydrogenase family protein & 5.0 & 9.0 & same phenotype \\
\hline BR 516 & $\begin{array}{l}\text { Brassica rapa subsp. pekinensis clone KBrB028I01, } \\
\text { complete sequence }\end{array}$ & 5.0 & 9.0 & same phenotype \\
\hline BR 517 & $\begin{array}{l}\text { ATP binding / kinase/ protein kinase/ protein } \\
\text { serine/threonine kinase/ protein tyrosine kinase (NAK) }\end{array}$ & 5.0 & 9.0 & same phenotype \\
\hline BR 518 & $\begin{array}{l}\text { Arabidopsis thaliana ATS1; glycerol-3-phosphate } \\
\text { O-acyltransferase (ATS1) mRNA, complete cds }\end{array}$ & 3.0 & 9.0 & same phenotype \\
\hline BR 519 & Arabidopsis thaliana HVA22J (HVA22-LIKE PROTEIN J) & 5.0 & 9.0 & same phenotype \\
\hline BR 520 & $\begin{array}{l}\text { Arabidopsis thaliana COX6B (CYTOCHROME C } \\
\text { OXIDASE 6B); cytochrome-c oxidase (COX6B) mRNA, } \\
\text { complete cds }\end{array}$ & 5.0 & 9.0 & same phenotype \\
\hline BR 521 & Zea mays clone 10882 mRNA sequence & 5.0 & 9.0 & same phenotype \\
\hline BR 522 & hypothetical protein, mRNA & 3.0 & 9.0 & same phenotype \\
\hline BR 523 & $\begin{array}{l}\text { Arabidopsis thaliana AtMAPR2 (Arabidopsis thaliana } \\
\text { membrane-associated progesterone binding protein 2); } \\
\text { heme binding (AtMAPR2) mRNA, complete cds }\end{array}$ & 5.0 & 9.0 & same phenotype \\
\hline BR 524 & inorganic pyrophosphatase family protein, mRNA & 5.0 & 9.0 & same phenotype \\
\hline BR 525 & unknown gene function & 5.5 & 9.0 & same phenotype \\
\hline BR 526 & PsbQ2 mRNA for oxygen-evolving enhancer protein 3-2 & 5.0 & 9.0 & same phenotype \\
\hline BR 527 & $\begin{array}{l}\text { Brassica rapa clone } 231 \text { CLA1-like protein mRNA, } \\
\text { complete cd }\end{array}$ & 5.0 & 9.0 & same phenotype \\
\hline BR 528 & $\begin{array}{l}\text { NAK; ATP binding / kinase/ protein kinase/ protein } \\
\text { serine/threonine kinase/ protein tyrosine kinase (NAK) } \\
\text { mRNA }\end{array}$ & 5.0 & 9.0 & same phenotype \\
\hline BR 529 & unknown gene function & 6.0 & 9.0 & same phenotype \\
\hline BR 530 & Myb family transcription factor & 5.2 & 9.0 & same phenotype \\
\hline BR 531 & Zea mays clone 14041 mRNA sequence & 5.0 & 9.0 & same phenotype \\
\hline
\end{tabular}


Appendix Table 1. Continued.

\begin{tabular}{|c|c|c|c|c|}
\hline Code & Gene Function & $\begin{array}{l}\text { Cold } \\
\text { stress score }^{\mathrm{a}}\end{array}$ & $\begin{array}{l}\text { Salinity } \\
\text { stress score }^{b}\end{array}$ & Observed phenotype $^{c}$ \\
\hline BR 532 & Sterol 4-alpha-methyl-oxidase 2 (SMO2-2) & 5.0 & 9.0 & same phenotype \\
\hline BR 533 & hypothetical protein & 5.0 & 9.0 & more taller plant height \\
\hline BR 534 & hypothetical protein & 4.5 & 9.0 & same phenotype \\
\hline BR 535 & mRNA for ACC oxidase (ACC0x2) & 5.0 & 9.0 & same phenotype \\
\hline BR 536 & hypothetical protein & 5.0 & 9.0 & same phenotype \\
\hline BR 537 & $\begin{array}{l}\text { Brassica rapa subsp. pekinensis clone } \mathrm{KBrB} 021 \mathrm{M} 22 \text {, } \\
\text { complete sequence }\end{array}$ & 5.0 & 9.0 & same phenotype \\
\hline BR 538 & hypothetical protein & 5.0 & 9.0 & same phenotype \\
\hline BR 539 & Raphanus sativus SAUR gene & 5.0 & 9.0 & same phenotype \\
\hline BR 541 & LHCB4.2 (light harvesting complex PSII) & 3.0 & 9.0 & $\begin{array}{l}\text { more taller plant height, } \\
\text { longer panicle length }\end{array}$ \\
\hline BR 542 & $\begin{array}{l}\text { Brassica rapa subsp. pekinensis clone } \mathrm{KBrB} 048 \mathrm{~F} 07 \text {, } \\
\text { complete sequence }\end{array}$ & 5.0 & 9.0 & same phenotype \\
\hline BR 544 & $\begin{array}{l}\text { Brassica rapa subsp. pekinensis clone KBrH003N18, } \\
\text { complete sequence }\end{array}$ & 5.0 & 9.0 & more taller plant height \\
\hline BR 545 & $\begin{array}{l}\text { Arabidopsis thaliana mRNA for } 50 \text { S ribosomal protein L3, } \\
\text { complete cds, clone: RAFL04-10-N10 }\end{array}$ & 5.0 & 9.0 & more taller plant height \\
\hline BR 546 & $\begin{array}{l}\text { Arabidopsis thaliana ATNUDX19 (ARABIDOPSIS } \\
\text { THALIANA NUDIX HYDROLASE HOMOLOG 19); } \\
\text { hydrolase/ metal ion binding (ATNUDX19) mRNA, } \\
\text { complete cds }\end{array}$ & 4.0 & 9.0 & more taller plant height \\
\hline BR 547 & UDP-galactose transporter 3 (ATUTR3) & 3.0 & 5.0 & same phenotype \\
\hline BR 548 & $\begin{array}{l}\text { A. lyrata subsp. lyrata inorganic pyrophosphatase family } \\
\text { protein, mRNA }\end{array}$ & 5.0 & 9.0 & more taller plant height \\
\hline BR 549 & $\begin{array}{l}\text { BcRUBP mRNA for ribulose 1,5-bisphosphate } \\
\text { carboxylase/oxygenase }\end{array}$ & 5.0 & 9.0 & more taller plant height \\
\hline BR 550 & $\begin{array}{l}\text { Arabidopsis thaliana ATRDH2 (ARABIDOPSIS } \\
\text { THALIANA RHODANESE HOMOLOGUE 2); } \\
\text { 3-mercaptopyruvate sulfurtransferase/ thiosulfate } \\
\text { sulfurtransferase (ATRDH2) mRNA, complete cds }\end{array}$ & 5.0 & 9.0 & shorter plant height \\
\hline BR 551 & $\begin{array}{l}\text { Arabidopsis thaliana RNA binding (AT4G39040) mRNA, } \\
\text { complete cds }\end{array}$ & 5.0 & 5.0 & same phenotype \\
\hline BR 552 & ribosomal protein S6 family protein & 5.0 & 9.0 & same phenotype \\
\hline BR 553 & $\begin{array}{l}\text { Brassica rapa PsbQ2 mRNA for oxygen-evolving enhancer } \\
\text { protein } 3-2 \text {, complete cds }\end{array}$ & 5.0 & 9.0 & same phenotype \\
\hline BR 554 & transducin family protein, mRNA & 5.0 & 9.0 & same phenotype \\
\hline BR 555 & $\begin{array}{l}\text { Brassica rapa subsp. pekinensis clone KBrB034A02, } \\
\text { complete sequence }\end{array}$ & 5.0 & 9.0 & same phenotype \\
\hline BR 556 & Hypothetical protein, mRNA & 5.0 & 9.0 & more taller plant height \\
\hline BR 557 & BnD21 mRNA sequence & 5.0 & 5.0 & more taller plant height \\
\hline BR 558 & unknown gene function & 5.0 & 9.0 & more taller plant height \\
\hline BR 560 & B.oleracea mRNA for ACC oxidase (ACC0x2) & 5.0 & 9.0 & same phenotype \\
\hline BR 561 & $\begin{array}{l}\text { Arabidopsis thaliana COX6B (CYTOCHROME C } \\
\text { OXIDASE 6B); cytochrome-c oxidase (COX6B) mRNA, } \\
\text { complete cds }\end{array}$ & 5.0 & 5.8 & longer culm length \\
\hline
\end{tabular}


Appendix Table 1. Continued.

\begin{tabular}{|c|c|c|c|c|}
\hline Code & Gene Function & $\begin{array}{l}\text { Cold } \\
\text { stress score }^{\mathrm{a}}\end{array}$ & $\begin{array}{l}\text { Salinity } \\
\text { stress score }^{b}\end{array}$ & Observed phenotype $^{\mathrm{c}}$ \\
\hline BR 562 & $\begin{array}{l}\text { Arabidopsis thaliana protein binding / zinc ion binding } \\
\text { (AT5G45100) mRNA, complete cds }\end{array}$ & 5.0 & 9.0 & same phenotype \\
\hline BR 563 & $\begin{array}{l}\text { Brassica rapa subsp. pekinensis clone KBrB036G18, } \\
\text { complete sequence }\end{array}$ & 5.0 & 9.0 & same phenotype \\
\hline BR 566 & $\begin{array}{l}\text { Arabidopsis thaliana ALB3 (ALBINO 3); } \\
\text { P-P-bond-hydrolysis-driven protein transmembrane } \\
\text { transporter (ALB3) mRNA, complete cds }\end{array}$ & 5.0 & 9.0 & same phenotype \\
\hline BR 567 & Zea mays clone 12993 mRNA sequence & 9.0 & 9.0 & same phenotype \\
\hline BR 569 & Zea mays clone 14041 mRNA sequence & 5.0 & 9.0 & same phenotype \\
\hline BR 571 & $\begin{array}{l}\text { Arabidopsis thaliana mRNA for putative mrp protein, } \\
\text { complete cds, clone: RAFL05-19-J04 }\end{array}$ & 5.0 & 9.0 & same phenotype \\
\hline BR 572 & $\begin{array}{l}\text { Brassica rapa clone } 231 \text { CLA1-like protein mRNA, } \\
\text { complete cds }\end{array}$ & 5.0 & 9.0 & same phenotype \\
\hline BR 579 & Zea mays clone 20053 mRNA sequence & 5.0 & 9.0 & same phenotype \\
\hline BR 734 & $\begin{array}{l}\text { Arabidopsis thaliana PDCB1 (PLASMODESMATA } \\
\text { CALLOSE-BINDING PROTEIN 1); callose binding / } \\
\text { polysaccharide binding (PDCB1) mRNA, complete cds }\end{array}$ & 5.0 & 9.0 & same phenotype \\
\hline BR 582 & isoflavone reductase family protein & 5.0 & 9.0 & same phenotype \\
\hline BR 583 & hypothetical protein & 5.0 & 9.0 & same phenotype \\
\hline BR 525 & disease resistance response protein & 5.0 & 6.8 & same phenotype \\
\hline BR 633 & ribosomal protein L9 family protein & 5.0 & 9.0 & same phenotype \\
\hline BR 640 & $\begin{array}{l}\text { TMS membrane family protein / tumour differentially } \\
\text { expressed (TDE) family protein }\end{array}$ & 5.0 & 9.0 & same phenotype \\
\hline BR 660 & translational inhibitor protein like & 5.0 & 9.0 & same phenotype \\
\hline BR 670 & $\begin{array}{l}\text { RPL9 (RIBOSOMAL PROTEIN L9); structural constituent } \\
\text { of ribosome (RPL9) }\end{array}$ & 5.0 & 9.0 & same phenotype \\
\hline BR 700 & tonoplast intrinsic protein bobTIP26-1 & 5.0 & 9.0 & same phenotype \\
\hline BR 708 & ATPHB2 (PROHIBITIN 2) (ATPHB2) & 5.0 & 9.0 & same phenotype \\
\hline BR 721 & unknown protein & 5.0 & 5.3 & same phenotype \\
\hline BR 725 & 40S ribosomal protein S4 (RPS4A) & 5.0 & 9.0 & same phenotype \\
\hline BR 735 & $\begin{array}{l}\text { SPP2 (SUCROSE-6F-PHOSPHATE } \\
\text { PHOSPHOHYDROLASE 2); catalytic/ magnesium ion } \\
\text { binding / phosphatase/ sucrose-phosphatase (SPP2) }\end{array}$ & 5.0 & 9.0 & same phenotype \\
\hline BR 743 & mitochondrial pyruvate dehydrogenase kinase (PDK) & 5.0 & 7.0 & same phenotype \\
\hline
\end{tabular}

\footnotetext{
A cold stress score: $1=$ seedling dark green, $3=$ seedling light green, $5=$ seedling yellow, $7=$ seedling brown, $9=$ seedling dead. The cold screening was conducted at Rural Development Administration, Chuncheon, Korea

${ }^{\mathrm{B}}$ Salinity stress score was based on the following at seedling stage: 1=Growth nearly normal, $3=$ Growth nearly normal but some leaves rolled sal), 5= Growth reduced and most leaves rolled(salt; only a few elongating, 7= Growth completely ceases; most leaves dry; some plants dying, $9=$ Almost all plants dead or dying

${ }^{\mathrm{C}}$ Observed phenotype was based on significant differences between the wilt type Gopum using pair-wise Dunnetts multiple comparison. The same phenotype means no significant differences in the agro-morphological character such as plant height, culm length, chlorophyll contents, panicle length, number of tillers.
} 